\title{
Secondary Economic Impact of Acid Deposition Control Legislation in Six Coal Producing States
}

\author{
M. J. Scott \\ S. J. Guthrie
}

December 1988

Prepared for

U.S. Environmental Protection Agency under a Related Services Agreement with the U.S. Department of Energy under Contract DE-AC06-76RLO 1830

Pacific Northwest Laboratory Operated for the U.S. Department of Energy by Battelle Memorial Institute 
Although the research described in this article has been funded wholly or in part by the United States Environmental Protection Agency (EPA), it has not been subjected to EPA review and therefore does not necessarily reflect the views of EPA and no official endorsement should be inferred.

\title{
DISCLAIMER
}

This report was prepared as an account of work sponsored by an agency of the United States Government. Neither the United States Government nor any agency thereof, nor Battelle Memorial Institute, nor any or their employees, makes any warranty, expressed or implied, or assumes any legal liability or responsibility for the accuracy, completeness, or usefulness of any information, apparatus, product, or process disclosed, or represents that its use would not infringe privately owned rights. Reference herein to any specific commercial product, process, or service by trade name, trademark, manufacturer, or otherwise does not necessarily constitute or imply its endorsement, recommendation, or favoring by the United States Covernment or any agency thereof, or Ballelle Memorial Institute. The views and opinions of authors expressed herein do not necessarily state or reflect those of the United States Government or any agency thereof.

\author{
PACIFIC NORTHWEST LABORATORY \\ operated by \\ BATTELLE MEMORIAL INSTITUTE \\ for the \\ UNITED STATES DEPARTMENT OF ENERGY \\ under Contract DE-ACO6-76RLO 1830
}

\begin{tabular}{|c|c|}
\hline \multicolumn{2}{|c|}{ Printed in the United States of America } \\
\hline \multicolumn{2}{|c|}{ Available from } \\
\hline \multicolumn{2}{|c|}{ National Technical Information Service } \\
\hline \multicolumn{2}{|c|}{ United State's Department of Commerce } \\
\hline \multicolumn{2}{|c|}{5285 Port Royal Road } \\
\hline \multicolumn{2}{|c|}{ Springfield, virginia 22161} \\
\hline \multicolumn{2}{|c|}{ NTIS Price Codes } \\
\hline \multicolumn{2}{|c|}{ Microfiche A01 } \\
\hline \multicolumn{2}{|c|}{ Printed Copy } \\
\hline & Price \\
\hline Pages & Codes \\
\hline $001-025$ & $\mathrm{~A} 02$ \\
\hline $026-050$ & $\mathrm{~A} 03$ \\
\hline $051-075$ & A04 \\
\hline $076-100$ & A05 \\
\hline $101-125$ & A06 \\
\hline $126-150$ & $\mathrm{~A} 07$ \\
\hline 151.175 & $\mathrm{~A} 0 \mathrm{~A}$ \\
\hline$\uparrow 76-200$ & $\mathrm{~A} 09$ \\
\hline $201-225$ & A10 \\
\hline $226-250$ & A11 \\
\hline $251-275$ & A12 \\
\hline $276-100$ & A13 \\
\hline
\end{tabular}


PNL -6669

UC- 11

FINAL REPORT

SECONDARY ECONOMIC IMPACT OF ACID

DEPOSITION CONTROL LEGISLATION IN

SIX COAL PRODUCING STATES

M. J. Scott

S. J. Guthrie

December 1988

Prepared for

U.S. Environmental Protection Agency under a Related Services Agreement with the U.S. Department of Energy under Contract DE-AC06-76RLO 1830

Pacific Northwest Laboratory

Richland, Washington 99352 


\section{EXECUTIVE SUMMARY}

Among the difficult policy questions on the U.S. environmental agenda is what (if anything) to do about emissions to the earth's atmosphere of pollutants that may result in "acid rain." The Congress has under consideration several pieces of legislation spelling out potential approaches to the problem and setting goals for emission reduction, mostly emphasizing the control of oxides of sulfur and nitrogen. As with many pieces of major environmental legislation, there could be economic "winners" and "losers" from its implementation. Significant policy concern has been expressed concerning the dollar costs to the nation's economy of achieving the intended effects of the legislation and the potential impacts on economic activity--in particular, losses of both coal mining and secondary service sector employment in states and regions dependent on the mining of high sulfur coal.

There are several direct economic effects of regulations such as those contemplated by the acid rain control legislation currently under consideration in the Congress. One of the more obvious effects was judged to be the switching from high sulfur coal to low sulfur coal. This would result in increases in employment and coal business procurements in low sulfur coal mining regions, but also would result in lower employment and lower coal business procurements in high sulfur coal mining areas than otherwise would have prevailed. The potential negative effects were the immediate policy concern that motivated this study and are the focus of this report.

This study was funded jointly by two offices of the U.S. Environmental Protection Agency (EPA):

Office of Program Development, office of Air and Radiation

and the

Office of Policy Analysis, Office of Policy, Planning and Evaluation

The study was comissioned as a preliminary effort by the Pacific Northwest Laboratory (PNL) to evaluate some specific employment effects associated with acid rain control options. At EPA's request, the study 
estimated the indirect and induced ${ }^{(a)}$ employment changes associated with changes in direct coal mining employment in selected states. This project is part of a long-standing commitment by PNL to support and conduct analyses for $D O E$, EPA, and other federal agencies, of economic issues surrounding acid rain and other energy-related environmental problems.

\section{SCOPE OF THE STUDY}

The states selected for the analysis are those in which losses in high sulfur coal production are expected as a result of many acid rain control proposals. It is important to note that in focusing on these states and on coal mining employment only, the project cannot capture the complete picture of national employment and economic impacts of acid rain control. The selected scope of the study highlights the most obvious negative employment effects of such a program. It should be recognized that there are offsetting positive effects in other regions and industrial sectors which are not accounted for in this study. It was necessary to limit the scope of this preliminary effort, and the negative coal mining impacts appear to be the most politicaliy sensitive of the potential employment effects.

The two actual pieces of legislation considered in this report are the Proxmire and Mitchell Bills. The Proxmire Bill (Senate Bill 316--"Acid Deposition Emissions Reduction Act") has as its goal reducing sulfur dioxide emissions $\left(\mathrm{SO}_{2}\right)$ from electric utility coal-fired power plants below 1980 levels in the 31 eastern states by about 5 million tons (32\%) below 1980 emission levels by 1995 and 9 million tons (58\%) below 1980 levels by the year 2000. The Mitchell Bill (S. Bill 1894) applies to all 48 contiguous

(a) Indirect economic impacts in this report are those changes in the value of goods and services, employment, and personal income produced in the entire state economy that occur because coal mining firms change their purchases of non-labor inputs to production. Induced impacts are those changes in output, employment, and personal income that occur in the entire state economy because of changes in the total compensation (wages and benefits) paid to coal mining workers as the level of coal mining activity changes. Both categories of effects can be expected to occur primarily offsite (away from the mine), and mainly in the service economy. 
states and to industrial as well as electric utility emissions. It is some what more ambitious than the Proxmire Bill in that it attempts to reach more stringent goals earlier and applies both to utility power plants and to industry. The assumed target reduction for $\mathrm{SO}_{2}$ in the Mitchell Case is about 5 million tons nationwide by 1995. The corresponding year $2000 \mathrm{goal}$ is 12 million tons nationwide versus 9 million in the Proxmire Bill. Actual reductions of emissions in both cases are somewhat greater than the targets because the targets were based on 1980 emissions and emissions were projected to grow in the absence of acid deposition control legislation. The remaining cases examined in the report are sensitivity cases. The results for these cases are described in chapters 2.0 and 4.0 of the main report.

The Proxmire and Mitchell Bills call for varying degrees of reduced emissions of sulfur from power plants, have been predicted to cause switching from high to low sulfur coal, and may also force utilities to install more effective scrubbers. The most obvious of the negative local economic effects of acid deposition control is expected to be the effects of coal switching on six traditional coal producing states in the Appalachian and Midwestern coal producing regions: the states of Illinois, Indiana, Kentucky, Ohio, Pennsylvania, and West Virginia. Kentucky and West Virginia are further divided into Eastern and Western Kentucky and Northern and Southern West Virginia because of differences in the types of coal and coal production technologies in the subareas.

\section{DESCRIPTION OF IMPACTS}

Table S.1 shows the overall effects of the two main cases examined in the study on selected measures of economic activity in the six states. The selected measures are frequently used to monitor the level of economic activity in regional economies and highlight the distributional effects of the legislation. These estimates include the direct economic effects of changes in coal production on output, worker income and employment and the secondary (indirect and induced) offsite impacts associated with purchases by the coal industry and coal workers spending their salaries in the local economy. The figures shown in Table S.l are cumulative and relative--that is, they represent how much higher or lower output, employment, and income 
TABLE S.1. Selected Economic 1mpacts of Acid Deposition Legislation Cases in Six States(a)

\begin{tabular}{|c|c|c|c|c|c|c|c|c|}
\hline \multirow[b]{2}{*}{ Case and State } & \multicolumn{2}{|c|}{$\begin{array}{l}\text { Change in } \\
\text { Coal Pro- } \\
\text { duct ion } \\
\text { (Milliog } \\
\text { Tons) (b) }\end{array}$} & \multicolumn{3}{|c|}{$\begin{array}{l}\text { Cumulative Direct } \\
\text { Economic Impac }\end{array}$} & \multicolumn{3}{|c|}{$\begin{array}{c}\text { Cumulative Direct and Secondary } \\
\text { Economic Impact in } 1995\end{array}$} \\
\hline & & $\frac{1(b)}{2000}$ & $\begin{array}{l}\text { Output } \\
\left(10^{6} s\right)\end{array}$ & $\begin{array}{l}\text { lncome } \\
\left(10^{6} \$\right)\end{array}$ & $\begin{array}{l}\text { Emp Joyment } \\
\text { (Jobs) }\end{array}$ & $\begin{array}{l}\text { Output } \\
\left(10^{6} \$\right)\end{array}$ & $\begin{array}{l}\text { Income } \\
\left(10^{6} \$\right)\end{array}$ & $\begin{array}{l}\text { Employment } \\
\text { (Jobs) }\end{array}$ \\
\hline $\begin{array}{l}\text { Proxmire Bill: } \\
\text { l11inois } \\
\text { Indiana } \\
\text { Kentucky }\end{array}$ & $\begin{array}{l}-13 \\
<-1\end{array}$ & $\begin{array}{r}-46 \\
-1\end{array}$ & $\begin{array}{r}\$-887 \\
<-1\end{array}$ & $\$-269$ & $\begin{array}{r}-8,050 \\
-100\end{array}$ & $\begin{array}{r}-3,139 \\
-53\end{array}$ & $\begin{array}{r}-952 \\
-15\end{array}$ & $\begin{array}{r}-29,050 \\
-550\end{array}$ \\
\hline $\begin{array}{l}\text { Eastern } \\
\text { Western } \\
\text { Total } \\
\text { Ohio } \\
\text { Pennsylvania } \\
\text { West Virginia }\end{array}$ & $\begin{array}{r}18 \\
-10 \\
8 \\
-14 \\
-3\end{array}$ & $\begin{array}{r}25 \\
-11 \\
14 \\
-15 \\
-25\end{array}$ & $\begin{array}{r}997 \\
-531 \\
466 \\
-1,007 \\
-199\end{array}$ & $\begin{array}{r}323 \\
-157 \\
166 \\
-306 \\
-71\end{array}$ & $\begin{array}{r}12,350 \\
-5,650 \\
6,700 \\
-10,250 \\
-1,950\end{array}$ & $\begin{array}{r}1,400 \\
-585 \\
815 \\
-1,079 \\
-1,655\end{array}$ & $\begin{array}{r}450 \\
-173 \\
277 \\
-328 \\
-588\end{array}$ & $\begin{array}{r}16,700 \\
-6,150 \\
10,550 \\
-10,450 \\
-16,850\end{array}$ \\
\hline $\begin{array}{l}\text { Northern } \\
\text { Southern } \\
\text { Total } \\
\text { Six State Total }\end{array}$ & $\begin{array}{r}-8 \\
13 \\
5 \\
-17\end{array}$ & $\begin{array}{r}-11 \\
17 \\
6 \\
-67\end{array}$ & $\begin{array}{r}-412 \\
669 \\
257 \\
\$-1,370\end{array}$ & $\begin{array}{r}-128 \\
265 \\
137 \\
\$-342\end{array}$ & $\begin{array}{r}-4,200 \\
7,850 \\
3,650 \\
-9,900\end{array}$ & $\begin{array}{r}-566 \\
930 \\
364 \\
\$-4,760\end{array}$ & $\begin{array}{r}-175 \\
354 \\
179 \\
\$-1,428\end{array}$ & $\begin{array}{r}-5,200 \\
10,700 \\
5,500 \\
-40,900\end{array}$ \\
\hline $\begin{array}{l}\text { Mitchell Bill: } \\
\text { Illinois } \\
\text { lndiana } \\
\text { Kentucky }\end{array}$ & $\begin{array}{r}-13 \\
-1\end{array}$ & $\begin{array}{r}-45 \\
-4\end{array}$ & $\begin{array}{r}-887 \\
-53\end{array}$ & $\begin{array}{r}\$-269 \\
-15\end{array}$ & $\begin{array}{r}-8,050 \\
-540\end{array}$ & $\begin{array}{r}\$-3,071 \\
-213\end{array}$ & $\begin{array}{r}-932 \\
-60\end{array}$ & $\begin{array}{r}-28,400 \\
-2,100\end{array}$ \\
\hline $\begin{array}{r}\text { Eastern } \\
\text { Western } \\
\text { Total }\end{array}$ & $\begin{array}{r}16 \\
-10 \\
6\end{array}$ & $\begin{array}{r}13 \\
-14 \\
-1\end{array}$ & $\begin{array}{r}886 \\
-531 \\
355\end{array}$ & $\begin{array}{r}287 \\
-157 \\
130\end{array}$ & $\begin{array}{r}10,950 \\
-5,650 \\
5,300\end{array}$ & $\begin{array}{r}720 \\
-744 \\
-24\end{array}$ & $\begin{array}{r}233 \\
-220 \\
13\end{array}$ & $\begin{array}{r}8,700 \\
-7,850 \\
850\end{array}$ \\
\hline
\end{tabular}


TABLE S.1. (contd)

\begin{tabular}{|c|c|c|c|c|c|c|c|c|}
\hline \multirow[b]{2}{*}{ Case and State } & \multirow{2}{*}{\multicolumn{2}{|c|}{$\begin{array}{l}\text { Change in } \\
\text { Coal Pro- } \\
\text { duction } \\
\text { (Millign } \\
\text { Tons) (b) } \\
\end{array}$}} & \multirow{2}{*}{\multicolumn{2}{|c|}{$\begin{array}{l}\text { Cumulative Direct } \\
\text { Economic Impad } \\
\text { Output Income } \\
\left(10^{5} \text { s) } \quad\left(10^{6} s\right)\right.\end{array}$}} & \multirow{2}{*}{$\begin{array}{l}\text { and Secondary } \\
\text { in } 1995 \\
\begin{array}{l}\text { Employment } \\
\text { (Jobs) }\end{array} \\
\end{array}$} & \multicolumn{2}{|c|}{$\begin{array}{l}\text { Cumulative Direct } \\
\text { Economic Impac }\end{array}$} & \multirow{2}{*}{$\begin{array}{l}\text { and Secondary } \\
\mathrm{t} \text { in } 1995 \\
\begin{array}{c}\text { Employment } \\
\text { (Jobs) }\end{array}\end{array}$} \\
\hline & & & & & & $\begin{array}{l}\text { output } \\
\left(10^{5} \$\right)\end{array}$ & $\begin{array}{l}\text { Income } \\
\left(10^{6} \mathrm{~s}\right)\end{array}$ & \\
\hline $\begin{array}{l}\text { Ohio } \\
\text { Pennsylvania } \\
\text { West Virginia }\end{array}$ & $\begin{array}{r}-12 \\
-3\end{array}$ & $\begin{array}{l}-13 \\
-16\end{array}$ & $\begin{array}{l}-864 \\
-199\end{array}$ & $\begin{array}{r}-269 \\
-71\end{array}$ & $\begin{array}{l}-8,750 \\
-1,950\end{array}$ & $\begin{array}{r}-936 \\
-1,059\end{array}$ & $\begin{array}{l}-284 \\
-377\end{array}$ & $\begin{array}{r}-9,100 \\
-10,800\end{array}$ \\
\hline $\begin{array}{l}\text { Northern } \\
\text { Southern } \\
\text { Total } \\
\text { Six State Total }\end{array}$ & $\begin{array}{r}-8 \\
11 \\
3 \\
-20\end{array}$ & $\begin{array}{r}-5 \\
9 \\
4 \\
-75\end{array}$ & $\begin{array}{r}-412 \\
566 \\
154 \\
\$-1,493\end{array}$ & $\begin{array}{r}-128 \\
224 \\
96 \\
\$-390\end{array}$ & $\begin{array}{r}-4,200 \\
6,650 \\
2,450 \\
-11,600\end{array}$ & $\begin{array}{r}-257 \\
492 \\
235 \\
\$-5,068\end{array}$ & $\begin{array}{r}-80 \\
188 \\
108 \\
-1,530\end{array}$ & $\begin{array}{r}-2,350 \\
5,650 \\
3,300 \\
-46,300\end{array}$ \\
\hline
\end{tabular}

(a) Impacts shown are relative to the base case level that would have prevailed in the absence of acid deposition control. Detail may not add to total because of rounding error. All dollar figures are in 1986 dollars.

(b) Changes in coal production are relative to the amount of production otherwise predicted to occur. They were supplied by EPA from reported simulations of the CEUM model by ICF, Inc. (ICF 1987a, 1987b, 1988a, 1988b). 
would eventually be relative to some base case situation that otherwise would have prevailed in the absence of acid deposition control and in the absence of mitigating actions. Thus, negative changes in employment shown in Table S.1 represent lower numbers of job slots than otherwise would have prevailed rather than outright employment losses. In particular, they do not represent layoffs of persons currently employed in these states but rather lower future economic opportunities.

1. Under either bill in the six state area the overall economic impacts are significant, ranging from about $\$ 1.4$ billion in lower output and 10,000 fewer jobs in 1995 to about $\$ 5$ billion dollars in lower output and 40,000 to 46,000 fewer jobs in the year 2000. The overall effects, however, mask some significant distributional effects. Most of the impacts are felt in just three states-Illinois, Ohio, and Pennsylvania. Kentucky and West Virginia actually gain statewide jobs and income relative to the base case because economic growth in the low sulfur coal mining areas "washes out" the adverse impacts in high sulfur areas (although the high sulfur areas in both states still suffer a relative loss in economic activity). In Indiana, the effects of the legislation are approximately neutral. In addition, although the Mitchell Bill has the greater overall net regional economic impact on the six states, the Proxmire Bill actually has a more profound effect in the individual jurisdictions. The smaller net regional effect is coincidental and dependent on differences in the relative sizes of the changes in production and relative sizes of the various state economic multipliers.

2. The absolute impacts shown in Table S.I represent less than one percent of the 1986 level of economic activity in the states in which they occur. However, it is expected that most of these effects would be concentrated in the coal mining counties in these states and could represent profound impacts in those counties. In Illinois, for example, over half of the state's coal production and over half of the operating mines in 1986 were concentrated in just five counties: Franklin, Macoupin, Perry, Randolf, and Saline. 
3. Sensitivity cases confirmed the importance of scrubber technology in reducing the economic effects of changing coal production. These differences are also apparent in Table S.1. The Mitchell Bill requires 12 million tons of annual sulfur emissions reduction from 1980 emissions levels by the year 2000, while the Proxmire Bill requires 9 million tons reduction. However, the Mitchell Bill relies more heavily on scrubbers and as a consequence has a less intrusive impact on coal production and economic activity in the individual coal producing states. Even the Mitchell Bill's greater overall net economic impact is less than proportional to the stricter sulfur emissions goal.

\section{METHODOLOGY, LIMITATIONS, AND UNCERTAINTIES}

Direct economic effects were calculated from forecasted changes in coal production estimated by ICF, Inc. using their Coal and Electric Utilities Model (CEUM). Changes in employment were estimated by ICF or by PNL researchers using CEUM model results. Other economic effects were estimated from CEUM coal production by PNL. Details of these forecasts can be found in the report in Chapter 4 . The secondary offsite economic effects of coal switching discussed in this study were estimated using the state economic multipliers computed in the Regional Input Output Modeling System II of the Bureau of Economic Analysis, U.S. Department of Commerce (RIMS II).

The RIMS II methodology, while well known and well-tested, contains significant sources of uncertainty. These sources of uncertainty include the effects of intrastate trade, interstate trade, and labor productivity changes over time in both the coal mining sector and the rest of the state economies. Another source of uncertainty is the extent to which economic growth induces state and local government spending and business investment, an effect not accounted for in the RIMS II multipliers. Finally, other seemingly valid multipliers are available from locally developed models for some of the coal producing states and it is not obvious whether the RIMS II or the alternative methodology is the better model. 



\section{CONTENTS}

EXECUTIVE SUMMARY ................... i i i

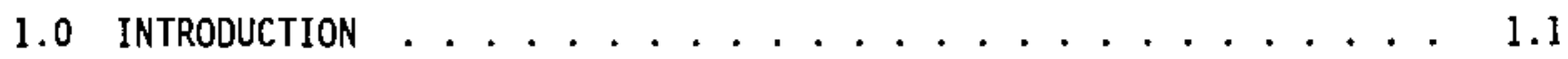

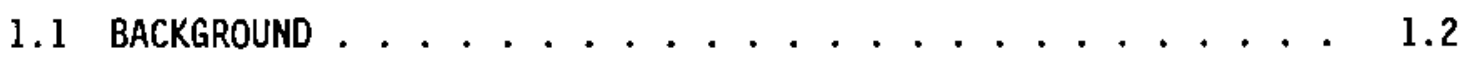

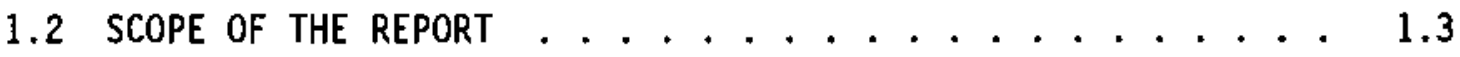

1.3 Limitations TO THE SCOPE . . . . . . . . . . . . . . 1.4

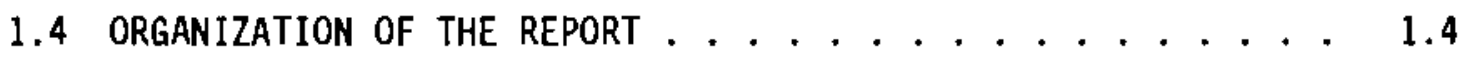

2.0 FINDINGS, CONCLUSIONS, AND RECOMMENDATIONS ........ 2.1

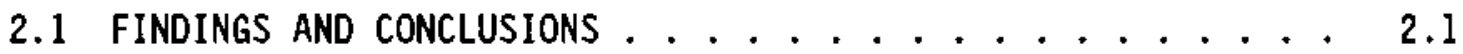

2.2 SOURCES OF UNCERTAINTY AND LIMITATIONS IN THE

2.2.1 Intrastate Trade Effects . . . . . . . 2.5

2.2.2 Interstate Trade . . . . . . . . . . 2.6

2.2.3 Labor Productivity Changes . . . . . . . . 2.7

2.2.4 Induced Government Spending and Business

2.2.5 Multipliers from Other Models . . . . . . . . 2.7

2.3 RECOMMENDATIONS . . . . . . . . . . . . . . . . . . . 2.8

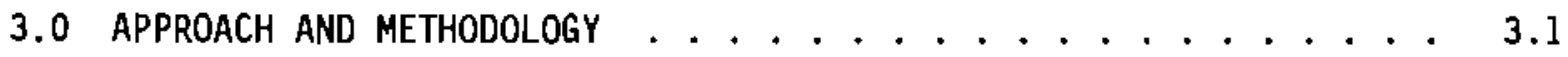

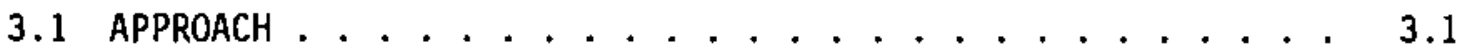

3.2 DATA SDURCES . . . . . . . . . . . . . . . . 3.4

3.3 ADJUSTMENTS TO THE RIMS II MULTIPLIERS . . . . . . . . 3.5

3.4 ECONOMIC MULTIPLIERS USED IN THE STUDY . . . . . . . 3.8

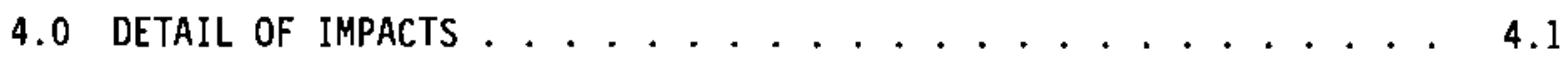

4.1 DESCRIPTION OF THE CASES .................... 4.1

4.1 .1 Proxmire $8 i 11 \ldots \ldots . \ldots . \ldots . . \ldots 4$ 
4.1.2 Mitchell Bill ............. 4.2

4.1.3 8 Million Ton Case (Without Required Scrubbers)... 4.3

4.1.4 8 Million Ton Case (With Required Scrubbers) . . . 4.4

4.1.5 6 Million Ton Case (With Required Scrubbers) . . . . 4.4

4.1 .6 Unexamined Cases ............ . . 4.4

4.1.7 Reasons for Selection of Cases ........ 4.5

4.2 DESCRIPTION OF ECONOMIC IMPACTS . . . . . . . . 4.6

4.2 .1 Direct Impacts ............ . . 4.7

4.2 .2 Secondary Impacts ............. 4.11

4.2 .3 0irect Plus Offsite Economic Impacts ...... . 4.14

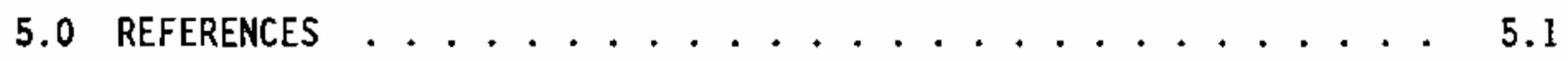

APPENDIX A - METHODOLOGICAL ISSUES . . . . . . . . . A.1

A.1 INTRASTATE DIFFERENCES IN ECONOMIC MULTIPLIERS . . . . . A.1

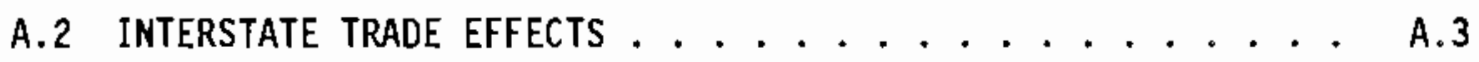

A.3 PRODUCTIVITY TRENDS . . . . . . . . . . . . A.4

A.4 EFFECTS OF STATE AND LOCAL GOVERNMENT SPENDING AND
BUSINESS INVESTMENT . . . . . . . . . . . . . . . . . . . . .

A.5 A COMPARISON OF IMPACTS WITH DIFFERENT MODELS . . . . A. 6 


\section{FIGURES}

3.1 Economic Impact Analysis Process for Changes in Coal

Production ................. 3.3

\section{TABLES}

S.1 Selected Economic Impacts of Acid Deposition Legislation

Cases in Six States................... vi

2.1 Summary of Economic Impacts of Changes in the Production of

Coal in Response to Acid Rain Control Legislation, Six-State

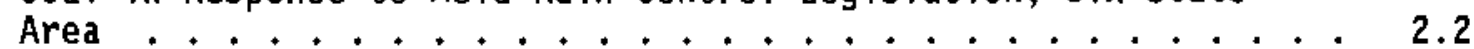

2.2 National Sulfur Emissions Control Goals Employment Impacts per Ton of Sulfur Emissions Controlled, and Employment Impact Per Ton of Lost Coal Production, 1995 and $2000 \ldots 2.5$

3.1 Production, Value of Production, Employment, and Earnings in the Coal Industry in the Six-State Study Area, 1986 . . . . 3.5

3.2 Information on Productivity Estimates For Coal Mining in ICF Documentation and Other Sources ............. 3.7

3.3 Offsite Employment Multipliers in Coal Mining With and Without Changes in Labor Productivity: 1986,1995 and $2000 \ldots . . .3$

3.4 Economic Multipliers Used in the Study . . . . . . . . 3.9

4.1 Selected Direct Economic Impacts on the Coal Industry of Acid Deposition Control in Six Coal Producing States . . . . . 4.8

4.2 Selected Offsite Economic Impacts of Acid Deposition Control In Six Coal Producing States .............. 4.12

4.3 Selected Direct Plu Offsite Economic Impacts of Acid Deposition Control in Six Coal Producing States . . . . . . . . 4.15

A.l Substate Differences in Coal Mining in Coal Producing Areas of Kentucky, 1986.................. A.2

A.2 Adjustments to the RIMS II State Economic Multipliers with Limited Indirect Response . . . . . . . . . . . . .

A.3 Index of Real Earnings per Worker 1970-1986 . . . . . . . A.4 
A.4 A Comparison of Type II Value Added Multipliers With Value Added Multiplier Effects that Include Business Investment and State and Local Government Spending Effects, for a Permanent \$1 lncrease in Washington State Exports in Selected Industries......................

A.5 List of Economic Models of the States Affected by Changes in Coal Production ................ A.7

A.6 Impacts of Changes in Coal Production in 1995 from the Mitchell Acid Rain Control Bill on State Economies Under Rims II Versus Local Alternative Models ... A.8

A.7 Type II Coal Mining Implicit Multipliers, 1995 . . . . . . . A.9 


\subsection{INTRODUCTION}

Among the difficult policy questions on the U.S. environmental agenda is what (if anything) to do about emissions to the earth's atmosphere of pollutants that may result in "acid rain." The Congress has under consideration several pieces of legislation spelling out potential approaches to the problem and setting goals for emission reduction, mostly emphasizing the control of oxides of sulfur and nitrogen. As with many pieces of major environmental legislation, there could be economic "winners" and "losers" from its implementation. Significant policy concern has been expressed concerning the dollar costs to the nation's economy of achieving the intended effects of the legislation and the potential impacts on economic activity--in particular, losses of both coal mining and secondary service sector employment in states and regions dependent on the mining of high sulfur coal.

There are several direct economic effects of regulations such as those contemplated by the acid rain control legislation currently under consideration in the Congress. One of the more obvious effects was judged to be the switching from high sulfur coal to low sulfur coal. This would result in increases in employment and coal business procurements in low sulfur coal mining regions, but also would result in lower employment and lower coal business procurements in high sulfur coal mining areas than otherwise would have prevailed. The potential negative effects were the immediate policy concern that motivated this study and are the focus of this report.

This study was funded jointly by two offices of the U.S. Environmenta] Protection Agency (EPA) :

Office of Program Development, office of Air and Radiation

and the

Office of Policy Analysis, Office of Policy, Planning and Evaluation

The study was commissioned as a preliminary effort by the Pacific Northwest Laboratory (PNL) to evaluate some specific employment effects associated with acid rain control options. At EPA's request, the study 
estimated the indirect and induced ${ }^{(a)}$ employment changes associated with changes in direct coal mining employment in selected states. This project is part of a long-standing commitment by PNL to support and conduct analyses for $D O E, E P A$, and other federal agencies, of economic issues surrounding acid rain and other energy-related environmental problems.

The states selected for the analysis are those in which losses in high sulfur coal production are expected as a result of many acid rain control proposals. It is important to note that in focusing on these states and on coal mining employment only, the project cannot capture the complete picture of national employment and economic impacts of acid rain control. The selected scope of the study highlights the most obvious negative employment effects of such a program. It should be recognized that there are offsetting positive effects in other regions and industrial sectors which are not accounted for in this study. It was necessary to limit the scope of this preliminary effort, and the negative coal mining impacts appear to be the most politically sensitive of the potential employment effects.

\subsection{BACKGROUND}

In addition to analyzing the expected environmental benefits of alternative proposals to control acid rain emissions, EPA is concerned with evaluating their overall economic impacts. "Acid Rain" is often used as a shorthand expression for both wet and dry deposition of acid or acidifying substances and a number of related regional air quality problems such as visibility aerosols. Major emissions of concern relative to this category of problems are sutfur dioxide $\left(\mathrm{SO}_{2}\right)$ and nitrogen oxides $\left(\mathrm{NO}_{\mathrm{X}}\right)$. Most proposals

(a) Indirect economic impacts in this report are those changes in the value of goods and services, employment, and personal income produced in the entire state economy that occur because coal mining firms change their purchases of non-labor inputs to production. Induced impacts are those changes in output, employment, and personal income that occur in the entire state economy because of changes in the total compensation (wages and benefits) paid to coat mining workers as the level of coal mining activity changes. Both categories of effects can be expected to occur primarily offsite (away from the mine), and mainly in the service economy. 
currently being considered focus primarily on reducing emissions of $\mathrm{SO}_{2}$ from the electric utility industry. The vast majority (95\% in 1986) of electric utility emissions of $\mathrm{SO}_{2}$ are produced by burning of coal in generating units. One major option for reducing these emissions is to switch fuels from coals high in sulfur to lower sulfur coals or to other fuels such as low sulfur oil or natural gas.

\subsection{SCOPE OF THE REPORT}

Fuel switching, al though of ten the most cost-effective emission reduction option from the utility companies' standpoint, raises concerns about losses in coal production in traditional coal mining areas which produce high sulfur coal. These reductions in coal production would, of course, translate into losses in job opportunities in coal mining in these regions. The following regions currently produce primarily high sulfur (i.e., above $1 \%$ ) coats and are expected to experience the most serious losses in coal mining employment under certain types of acid rain control proposals.

- Illinois

- Ohio

- Pennsylvania
- Indiana

- Western Kentucky

- Northern West Virginia

These regions are most 1 ikely to experience losses in coal mining employment as a result of proposed controls to reduce emissions of pollutants associated with acid rain and associated regional air pollution problems. They are included in the study for that reason. Also included are two regions which produce primarily low sulfur coal and are expected to benefit from many acid rain control bills.

- Eastern Kentucky

- Southern West Virginia

These regions are included because they are in states which also have high sulfur regions which may lose production. In those states it is important to track the regional gains and losses in employment.

PNL examined two actual pieces of legislation and three additional sensitivity cases to estimate selected economic impacts that would occur in a six state area in Appalachia and the Midwest as a result of changes in coal production if acid deposition controls were implemented. The two actual pieces of legislation considered in this report are the Proxmire and Mitchell 
Bills. The Proxmire Bill (Senate Bill 316--"Acid Deposition Emissions Reduction Act") has as its goal reducing sulfur dioxide emissions from electric utility coal-fired power plants below 1980 levels in the 31 eastern states by about 5 million tons per year (32\%) below 1980 levels by 1995 and 9 million tons per year (58\%) below 1980 levels by the year 2000. The Mitchell Bill (5. Bill 1894) applies to all 48 contiguous states and to industrial emissions as well as electric utility emissions. It is somewhat more ambitious than the Proxmire Bill in that it attempts to reach more stringent goals earlier and applies both to utility power plants and to industry. The assumed target reduction for $\mathrm{SO}_{2}$ in the Mitchell Case is about 5 million tons of sulfur per year nationwide by 1995 . The corresponding year 2000 goal is 12 million tons nationwide versus 9 million in the Proxmire Bill. Actual reductions of emissions in both cases are somewhat greater than the targets because the targets were based on 1980 emissions and emission rates were projected to grow in the absence of acid deposition control legislation.

\subsection{LIMITATIONS TO THE SCOPE}

Important employment effects not addressed in this study include the effects of increased coal production in the West, effects of investments in scrubbers and other control technologies, effects of changes in electricity prices, and changes in coal transportation services. Many of these effects are expected to be geographically diffused and difficult to quantify.

\subsection{ORGANIZATION OF THE REPORT}

The organization of the report is as follows. Section 2.0 discusses the findings, conclusions, and recommendations of the study and summarizes the estimates of economic impact. Section 3.0 describes the methods used to estimate the impacts of changes in coal mining activity. Section 4.0 discusses the impacts in additional detail. The report concludes with an appendix addressing a number of methodological issues. 


\subsection{FINDINGS, CONCLUSIONS, AND RECOMMENDATIONS}

The economic effects forecasts in this study were derived by two models by a process described in Chapter 3.0. Estimates of the direct effects of five acid deposition control bills on coal production and employment were supplied to PNL by EPA from runs of ICF, Inc.'s Coal and Electric Utilities Model (CEUM) through a previous contract agreement between EPA and ICF (ICF 1987a, 1987b, 1988a, 1988b). Selected other direct economic effects and the secondary (indirect and induced) offsite effects on economic output, employment, and personal income were calculated by PNL. Output, employment, and income measures are frequently used to monitor the level of economic activity in regional economies. Changes in these variables hightight the distributional effects of the legislation. These secondary impacts were calculated using the most recent state economic multipliers from the Regional Input Output Modeling System II of the Bureau of Economic Analysis, U.S. Department of Commerce (RIMS II). The direct changes in the value of output, earnings, and employment in coal mining were then added to the respective secondary effects to obtain the resulting total impacts on output, employment, and personal income in each coal producing region's respective state. Positive and negative impacts in each state were summed algebraically to determine the net impact on the six-state region.

The results were then checked for consistency with other economic data published for these regions and other economic multipliers available from other models (see Appendix A).

\subsection{EINDINGS AND CONCLUSIONS}

PNL found that the principal acid rain control legislation, through its effects on the production of coa7, may have significant impacts on statewide economic activity in the six Appalachian and Midwestern coal producing states analyzed in this study (Illinois, Indiana, Kentucky, Ohio, Pennsylvania, West Virginia). As is shown in Table 2.1, net regional impacts varied by production scenario; however, the following are some of the highlights of the impacts at the regional and subregional level. 
TABLE 2.1. Selected Economic lmpacts of Changes in the Production of Coal in Response to Acid Rain Control Legislation, Six-State Area (Illinois, Indiana, Kentucky, Ohio, Pennsylvania, West Virginia) (a)

\begin{tabular}{|c|c|c|c|c|c|c|c|c|}
\hline \multirow[b]{2}{*}{ Case and State } & \multicolumn{2}{|c|}{$\begin{array}{l}\text { Change in } \\
\text { Coal Pro- } \\
\text { duction } \\
\text { (Million } \\
\text { Tons) }\end{array}$} & \multicolumn{3}{|c|}{$\begin{array}{c}\text { Cumulative Direct and Secondary } \\
\text { Economic lmpact in } 1995 \\
\end{array}$} & \multicolumn{3}{|c|}{$\begin{array}{c}\text { Cumulative Direct and Secondary } \\
\text { Economic Impact in } 1995\end{array}$} \\
\hline & $\frac{T c}{\underline{1995}}$ & & $\begin{array}{l}\text { Output } \\
\left(10^{6} \$\right)\end{array}$ & $\begin{array}{l}\text { Income } \\
\left(10^{6} \$\right)\end{array}$ & $\begin{array}{l}\text { Employment } \\
\text { (Jobs) }\end{array}$ & $\begin{array}{r}\text { Output } \\
\left(10^{6} \$\right)\end{array}$ & $\begin{array}{l}\text { Income } \\
\left(10^{6} \$\right)\end{array}$ & $\begin{array}{l}\text { Employment } \\
\text { (Jobs) }\end{array}$ \\
\hline Proxmire 8ill: & -17 & -67 & $\$-1,370$ & $\$-342$ & $-9,950$ & $\$-4,764$ & $\$-1,428$ & $-40,900$ \\
\hline Mitchell Bill: & -20 & -75 & $-1,493$ & -390 & $-11,600$ & $-5,068$ & $-1,530$ & $-46,300$ \\
\hline $\begin{array}{l}8 \text { MT (Without } \\
\text { Required } \\
\text { Scrubbers) }\end{array}$ & -43 & -56 & $-3,161$ & -843 & $-25,000$ & $-4,034$ & $-1,187$ & $-33,800$ \\
\hline $\begin{array}{l}8 \text { MT (With } \\
\text { Required } \\
\text { Scrubbers) }\end{array}$ & -22 & -35 & $-1,563$ & -420 & $-12,950$ & $-2,464$ & -723 & $-21,100$ \\
\hline $\begin{array}{l}6 \text { MT (With } \\
\text { Required } \\
\text { Scrubbers) }\end{array}$ & -11 & -29 & -755 & -213 & $-6,500$ & $-2,040$ & -515 & $-16,350$ \\
\hline
\end{tabular}

(a) Sources: CEUM and RIMS II model results. 
- The overall impact of changes in coal mining resulting from acid deposition control legislation on the level of economic activity in the economies of the six Appalachian and Midwest states was negative. We project approximately 10,000 fewer jobs in 1995 than otherwise would have been present and around 40,000 to 46,000 fewer in the year 2000. Because they represent a lower level of economic activity in 1995 and 2000 than otherwise would have prevailed (that is, not accounting for other causes of economic growth, for example, or for mitigating actions that may reduce the impacts), these impacts primarily represent lowered relative economic opportunities for future workers rather than job losses for current workers.

- Overal1, the impact on coal mining and level of economic activity in the six-state region steming from the Mitchell Bi11 (S. 1894) was greater than that of the Proxmire Bill (S. 316), even though the difference is relatively smal1--13 to $17 \%$ in the year 2000--and less than proportional to the relative reduction in the level of sulfur emissions.

- In most cases, the net direct job and income losses in mining represented only about a third of the total impact on these measures of economic activity. This is because mining industry jobs are good paying jobs on average and exist in a relatively capital-intensive industry. Therefore, losses in production tend to eliminate a disproportionate share of state personal income and interindustry sales.

- Scrubbers significantly reduce the impact on coal mining and the resultant impact on the economies of the six coal producing states. The 6 Milition Ton Case (With Required Scrubbers) calls for a larger reduction in sulfur emissions in 1995 than either the Proxmire or Mitchell Bill. However, it requires smaller changes in production and shows impacts that are lower by a third than the Proxmire Case and lower by half than the Mitchell Case. Also, comparing the 
8 Million Ton Case (With Required Scrubbers) with the Proxmire Bill, which mandates a 9 million ton reduction in sulfur emissions, the 8 Million Ton Case has only about half the overall negative impact on the six-state region. Finaliy, comparing the two 8 Million Ton cases, we note that the 8 Million Ton Case (With Required Scrubbers) has half the negative impact of the 8 Million Ton Case (Without Required Scrubbers) in 1995 and is still one third lower by the year 2000 .

- Because of differences in sulfur content and coal production technology in the various states affected, economic impacts of changes in the level of coal production are not necessarily proportional to the reductions achieved in sulfur emissions in each scenario. However, because the economic impact methodology implicitly assumes that economic multipliers in each state are basically unaffected by the size of coal production changes, the economic impacts are roughly proportional to changes in coal production. This is i1lustrated in Table 2.2.

Overall, it appears that acid deposition control legislation would have a significant impact on the economies of the Midwest and Appalachia through changes in coal production and that the size of the impact does appear to depend on the form of implementation. However, which bill has the biggest impact is dependent on whether one focuses on the region or the state and whether scrubbers are required or not. In addition, this judgment depends on several uncertainties underlying the analysis described below.

\subsection{SOURCES OF UNCERTAINTY AND LIMITATIONS IN THE FORECASIS}

The accuracy of forecasted economic impacts contained in this study depends in part on the accuracy of the state economic multipliers computed in the RIMS II model. The RIMS II methodology, while well known and welltested (e.g., Cartwright et al. 1981), contains significant embedded sources of uncertainty. These sources of uncertainty include the effects of intrastate trade, interstate trade, and labor productivity changes over time in 
IABLE 2.2. National Sulfur Emissions Control Goals, Employment Impacts per Ton of Sulfur Emissions Controlled, and Emplpyment Impact Per Ton of Lost Coal Production, 1995 and $2000(\mathrm{a})$

\begin{tabular}{|c|c|c|c|c|c|}
\hline \multicolumn{2}{|c|}{$\begin{array}{l}\text { National Goal for } \\
\text { Sulfur Control }(b) \\
\text { (Million Tons/Yr) }\end{array}$} & \multicolumn{2}{|c|}{$\begin{array}{l}\text { Employment Lost } \\
\text { per Million Tons } \\
\text { Sulfur Controlled } \\
\end{array}$} & \multicolumn{2}{|c|}{$\begin{array}{c}\text { Employment Lost } \\
\text { per Million Tons } \\
\text { Lost Coal Production }\end{array}$} \\
\hline & & $\underline{1995}$ & $\underline{2000}$ & $\underline{1995}$ & 2000 \\
\hline 5 & 9 & 1,980 & 4,544 & 582 & 610 \\
\hline 5 & 12 & 2,320 & 3,858 & 580 & 617 \\
\hline 8 & 8 & 3,125 & 4,225 & 581 & 604 \\
\hline 8 & 8 & 1,613 & 2,638 & 586 & 602 \\
\hline 6 & 6 & 1,083 & 2,733 & 591 & 566 \\
\hline
\end{tabular}

(a) Sources: Computed from CEUM and RIMS II model results by the authors.

(b) Goals are stated relative to the 1980 emissions levels. Because economic and emissions growth has occurred since 1980 and is expected to continue in the absence of regulation, greater reductions in sulfur emissions are required than the goals suggest.

both the coal mining sector and the rest of the state economies. Another source of uncertainty, which is outside the model, is the extent to which economic growth induces state and local government spending and business investment, an effect not accounted for in the RIMS II multipliers. Finaliy, we note that other seemingly valid multipliers are available for some of the coal producing states. The RIMS II methodology is not the only one available.

\subsubsection{Intrastate Trade Effects}

The RIMS II coal sector multipliers used in this study are computed for each individual state and are assumed to apply to economic activity in all types of coal mining anywhere within a given state. They do not account for 
geographical concentration of some types of supporting industries or for the presence of statewide trade centers, or differences between technology in surface coal mining and underground mining. (a) This means for example that in a case where coal production increases in Eastern Kentucky were equal to coal production decreases in Western Kentucky, the RIMS II multipliers used in this study would produce equal secondary impacts per dollar of production for both changes and the net impact on the state would be approximately zero. In reality, different trading patterns probably exist in the two regions, and the net impact of equal and offsetting changes in coal production probably would not be zero, although the difference might be small.

\subsubsection{Interstate Trade}

Second, the RIMS II system does not account for interstate trading patterns. One state's economic activity does not affect another state's economy in the RIMS II system. This means for example that if production falls in Ohio but rises in Kentucky, the model records a full negative multiplier response of secondary economic losses in Ohio and a full positive multiplier response of secondary economic gains in Kentucky. Reality is undoubtedly more complicated, since many of the firms and industries supporting the coal industry in the two states sell to the entire Appalachian and Midwestern coal producing region. Thus, when coal production declines in ohio, the Ohio support sector would not necessarily shrink proportionately. Instead, sales that used to be made to ohio mines and miners by ohio firms might now be made across the border in Kentucky with no adverse impact on ohio secondary economic activity. Conversely, Kentucky supply firms would not necessarily gain business from an increase in Kentucky mining at the expense of their Ohio neighbors. In fact, some Kentucky firms that used to se11 in ohio might be adversely affected. We do not know the extent of such interstate linkages, but we were able to calculate that approximately one third of the total economic impact from changes in coal mining (25\% in West Virginia) is traceable

(a) While multipliers for surface mining and underground mining undoubtediy are different, the ICF forecasts used in the study and RIMS II multipliers do not distinguish between the two types of mining. 
to interindustry sales. These sales may or may not be affected when coal mining activity shifts between neighboring states.

\subsubsection{Labor Productivity Changes}

Next, we note that much of the estimated economic impact depends on assumptions concerning the unknown future rates of productivity improvement in coal mining and in the economy outside of mining. In the analysis reported in this study, we accepted the assumptions made by ICF under separate contract with EPA concerning future productivity in mining, which averaged about 3\% per year across the various producing states and areas. ICF staff emphasize that the productivity changes in mining are subject to considerable uncertainty, and depend upon (among other things) exactly which mines remain open under each scenario. Different rates of increase could lead to much different employment and wage impacts. Historical analys is of the wages in the 6-state area showed no obvious tendencies in labor productivity outside of mining, so no adjustments were made for this phenomenon. However, we suspect that the result of this assumption is a modest overestimate of secondary employment impacts.

\subsubsection{Induced Government Spending and Business Investment}

We also note that the RIMS II system implicitly assumes that there are no impacts on government spending or business investment in the study area as a result of changes in the production of the coal industry. However, this is unlikely, since state and local governments and the business sector will experience substantial decreases in income in some cases, and substantial increases in other areas. It is likely, therefore, that the secondary impact multipliers would understate the actual impacts to some degree as a result. Conway (1979) suggests that a model that includes both business investment and government spending effects may produce estimates of impacts that are around 25\% larger than the those produced by models such as RIMS II.

\subsubsection{Multipliers from Other Models}

We performed a survey of regional economic models developed by local forecasters to determine whether models other than RIMS II would produce similar estimates of economic impacts. (See Appendix A.) However, despite 
considerable effort, we could not completely reconcile the RIMS II multipliers with multipliers from locally produced models of the economies of Kentucky and West Virginia, the two states for which such comparisons were possible. Because we had questions concerning the local models that we were unable to resolve to our satisfaction, we could not determine whether the RIMS II or local model was the more likely to be correct.

\subsection{RECOMMENDATIONS}

Although we did not examine the secondary economic effects of changes in electricity prices resulting from applications of scrubbers and increases in coal costs to utilities, other costs of acid deposition legislation measure in the billions of dollars. (See Chapter 3.) To obtain a comprehensive picture of the economic impacts, PNL recommends that an assessment be made of the effects of investments in scrubbers, effects of electricity price increases, and effects of additional transportation charges for hauling coal at the national level using economic models appropriate for performing such calculations.

In the course of the analysis, we discovered that there are significant uncertainties concerning the actual intrastate and interstate linkages between the coal industry and the rest of the economy which could affect the size of economic impacts and in each state and might even change the identity of the "winners" and "losers". If specifying the winners and losers is important, we reconmend that a thorough industry study be performed to determine the actual pattern of intrastate and interstate economic linkages between the coal industry and other industries in the affected states. 


\subsection{APPROACH AND METHODOLOGY}

\subsection{APPROACH}

There are several predicted direct economic effects of regulations such as those contemplated by the acid rain control legislation currently under consideration in the congress. These are: 1) switching from high sulfur coal to low sulfur coal will result in increases in employment and coal business procurements of fuel, utilities, machinery and consumables in low sulfur coal mining regions but will result in lost employment and coal business procurements in high sulfur coal mining areas; 2) investments in scrubbers will result in additional construction and utility operations employment in regions where the scrubber investments take $\mathrm{place}$ and additional manufacturing activity in those regions that produce the scrubbing equipment; 3 ) due to coal importing, transportation employment in some regions may increase; 4) to the extent that electricity prices increase to cover the costs of coal switching and additional scrubbers, industrial costs of production may increase and industrial activity in some regions may decline; and 5) consumers faced with higher electricity costs will reduce their consumption both of electricity and of other goods because of lost purchasing power. One of the more obvious of the effects is expected to be the negative effects of coal switching on the level of economic activity in the Midwestern and Appalachian high-sulfur coal producing regions. It is the only impact analyzed in this report.

A few figures will give the reader a sense of the unexamined economic impacts outside the coal industry. Using the Coal and Electric Utility Model, ICF, Inc. estimates that the direct annual compliance costs of the Mitchell Bill to electric utilities would be $\$ 1.4$ billion in 1995 and $\$ 6.9$ billion for the year 2000 (ICF, Inc. 1988). This increment is roughly distributed as one-third capital cost, one-third operations and maintenance costs and one-third fuel costs. The economic impacts of increased capital investment and additional operations and maintenance expenses are not 
considered in this report. RCG/Hagler (1988) and Pechan and Associates (a) have translated the increase in direct utility costs into average increases of from $9 \%$ to $14 \%$ in year 2000 electrical rates in the most-affected states, assuming complete pass-through. This report does not discuss the economic impact of such changes in energy costs nor the impact of the associated capita] investments.

PNL used the following procedure in estimating the secondary (offsite) economic effects of coal mine closures and changes in coal production. We first derived cumulative multipliers for secondary statewide employment, income, and economic activity related to coal mining from regional economic models supplied by the Regional Input-Output Model System II (RIMS II) of the U.S Department of Commerce, Bureau of Economic Analysis (BEA). These cumulative secondary multipliers are ratios, equal to the change in statewide employment, income, or output that eventually would occur outside the coal industry per dollar of final demand for coal produced in the state. The RIMS II service of BEA provides input-output based output, earnings, and employment multipliers of the U.S. state and substate regional economies at the 39-sector level based on the 570-sector input-output table of the U.S. economy. Arthur D. Littie, Inc. previously used the RIMS approach in analyzing alternative acid rain control strategies in January 1985 (Arthur $D$. Little, Inc. 1985).

Because the analysis in this study concerns future changes in final demand for coal, and because these multipliers were estimated by BEA in specifjc years' dollars, it was necessary to make additional assumptions about future changes in the productivity of labor to derive the final multipliers used in the analysis, described later in this section. The final multipliers were multiplied times the corresponding change in final demand for coal in each of the coal mining regions. The basic data for estimating changes in final demand for coal were provided to PNL by EPA from the ICF, Inc., Coal

(a) E. H. Pechan and Associates, Inc. "Analysis of the Impacts of Senate Bill 1894 on the Electric Utility Industry." (Draft). E. H. Pechan and Associates, Springfield, Virginia, March 21, 1988. 
and Electric Utilities Model (CEUM) under a separate contract between EPA and ICF. These data are discussed briefly in Section 3.2.

Figure 3.1 shows the process used in the study to generate estimates of economic impact. In the first step shown in the figure, PNL converted the coal production impact data supplied for the years 1995 and 2000 from the Coal and Electric Utility Model into direct changes in the value of coal produced (approximate final demand in coal production). We used 1986 price data supp Tied by Energy Information Administration in Coal Production 1986

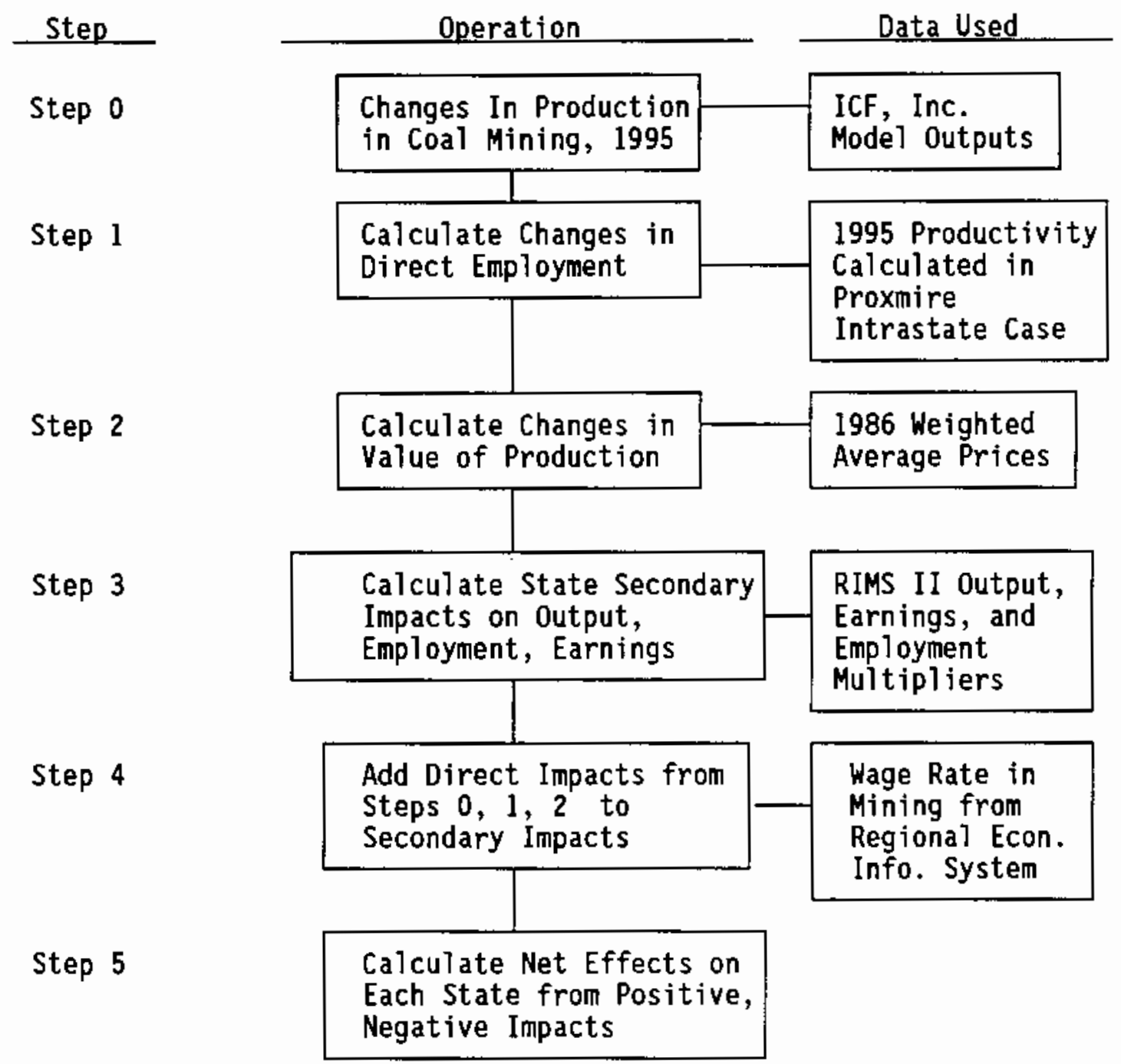

FIGURE 3.1. Economic Impact Analysis Process for Changes in Coal Production 
(EIA, 1988). Thus, all analysis is implicitly in constant 1986 dollars. In Step 2 PNL estimated changes in employment in each coal producing region, using 1995 and 2000 productivity estimates calculated from CEUM model results for base case future production (EPA Base Case) and for the group of mines affected by acid deposition control legislation. These productivity estimates reflect best available information on future labor productivity for average mines in each state in the EPA Base Case and for those mines that would be affected by acid rain control legislation. (In some cases, PNL received estimates of direct impact on employment. In those cases, the productivity relationship was not needed.)

In Step 3, the changes in final demand from Step 2 were multiplied times the appropriate RIMS II state input-output multipliers to obtain the secondary output, employment, and earnings effects in each state. The direct changes in the value of output, earnings, and employment in coal mining were then added in Step 4 to the respective secondary effects to obtain the total impacts of changes in each coal producing region on its respective state. Earnings in coal mining were estimated by multiplying the 1986 average earnings per worker in coal mining from $\mathrm{BEA}^{\prime}$ s Regional Economic Information System in each state times the change in productivity assumed in mining in the EPA Base Case. This calculation assumes that coal labor earnings would keep pace with productivity improvements in the sector. In Step 5 , the positive and negative impacts for each state were summed algebraically to determine the net impact.

The results were then checked for consistency with other economic data published for these regions and other economic multipliers available from other models. This comparative analysis is described in Appendix A.

\subsection{DATA SOURCES}

Estimates of the direct effects of the five acid deposition control bills on the coal mining industry were supplied to PNL by EPA from model runs of ICF, Inc.'s Coal and Electric Utilities Model through a separate contractual agreement between EPA and ICF (ICF 1987a, 1987b, 1988a, 1988b). EPA was able to supply the following outputs to PNL for the years 1995 and 2000: 
- Coal production by region

- Employment in coal mining, by region.

EPA was not able to supply information on regional earnings in coal mining or regional coal prices. PNL obtained estimates of earnings in coal mining from the Regional Economic Information System (REIS) of the U.S. Department of Commerce, Bureau of Economic Analysis (BEA). The REIS data include, for each state and county in the country, annual estimates of personal labor and proprietor income and employment by Standard Industrial Classification code as well as regional transfer payments and other non-labor components of income. Data on coal prices came from EIA (EIA 1988). Data on production, value of production, employment, and earnings in coal mining for 1986 are shown in Table 3.1.

\subsection{ADJUSTMENTS TO THE RIMS II MULTIPLIERS}

Both direct employment and coal production data were available from the ICF model on the so-called Proxmire "Intrastate Trading Case," a potential

TABLE 3.1. Production, Value of Production, Employment, and Earnings in the Coal Industry in the Six-State Study Area, 1986

\begin{tabular}{|c|c|c|c|c|}
\hline State & $\begin{array}{l}\text { Coal Production } \\
\text { (Thousand } \\
\text { Short Tons) (a) }\end{array}$ & $\begin{array}{l}\text { Value of } \\
\text { Production } \\
\text { (Million } \$ \text { (a) }\end{array}$ & Employment (b) & $\begin{array}{r}\text { Earnings } \\
\text { Millions } \\
\end{array}$ \\
\hline $\begin{array}{l}\text { Illinois } \\
\text { Indiana } \\
\text { Kentucky } \\
\text { Ohio } \\
\text { Pennsylvania } \\
\text { Nest Virginia }\end{array}$ & $\begin{array}{r}61,866 \\
32,852 \\
153,933 \\
36,441 \\
71,648 \\
129,907\end{array}$ & $\begin{array}{r}\$ 1,855 \\
833 \\
4,016 \\
1,195 \\
2,171 \\
4,014\end{array}$ & $\begin{array}{l}15,046 \\
5,703 \\
37,914 \\
10,756 \\
22,748(\mathrm{c}) \\
35,852\end{array}$ & $\begin{array}{c}\$ \quad 659 \\
261 \\
1,546 \\
477 \\
835(\mathrm{~d}) \\
1,529\end{array}$ \\
\hline
\end{tabular}

(a) Source: EIA, 1988, Appendix C.

(b) Source: BEA, Regional Economic Information System.

(c) BEA suppressed their estimate to avoid disclosure of individual company data. Estimated by PNL based on the ratio of workers in mining operations in 1980 (EIA 1988, Appendix C) to total workers in coal mining in 1980 (REIS).

(d) 8EA suppressed their estimate to avoid disclosure of individual company data. Estimated by PNL based on the 1982 ratio of average wages/worker in all mines to the earnings/worker in coal mines (REIS). 
scenario of acid deposition control. In this scenario by the year 1995, utility powerplants not subject to New Source Performance Standards are required to meet emission targets equal to 1980 emissions, minus $2.0 \mathrm{lb}$. per million Btu, or "excess" emissions on a statewide basis. The "excess" emissions refers to those emissions that resulted in 1980 from a state emitting more than an annual average of $2.0 \mathrm{lb}$. $\mathrm{SO}_{2}$ per million Btu consumed in the state. "Intrastate Trading" refers to the assumption that utilities already emitting less sulfur than specified under their emission targets in 1995 would be allowed to trade these extra "reductions" to other utilities in the same state.

The direct coal mining employment and production forecasts from the Proxmire Intrastate Trading Case permitted us to make estimates of labor productivity in coal mining in the states of interest for those mines that would be affected by acid deposition legisiation. Table 3.2 shows some resulting productivity estimates. As can be seen in the table, 1985 production per worker is about the same in the ICF data as it is in the Energy Information Administration's (EIA) data from Coal Production 1986 (EIA 1988). It is not clear exactly what differences may exist between the definitions of production and employment in the EIA data and in the ICF data. EIA, for example, excludes production and workers in mines producing less than 10,000 tons per year and general office workers, but includes workers in coal preparation facilities and development, shop, and yard work.

The 1995 data in Table 3.2 indicate three crucial aspects of the ICF estimates. First, the apparent average labor productivity at mines that reduce production in response to acid rain regulations is not the same as at the "average" mine in each producing region. (a) Second, regulation-induced shutdowns are not confined to the least productive mines. Third, the rate of improvement in average mining productivity forecasted in the base case varies

(a) Ideally, since economic theory of the firm says that wage rates and income shares are based on the value of the marginal productivity of labor, this discussion should relate to changes in marginal productivity of labor. Data were not available on marginal product. Implicitly, we are assuming the differences in marginal product between scenarios and regions over time correlate well with differences in average product. 
TABLE 3.2. Information on Productivity Estimates For coal Mining in ICF Documentation and Other Sources

\begin{tabular}{|c|c|c|c|c|c|}
\hline \multirow[b]{2}{*}{$\begin{array}{l}\text { State or Producing } \\
\text { Area } \\
\end{array}$} & \multicolumn{2}{|c|}{$\begin{array}{l}1985 \text { Average Production } \\
\text { Per Employee (Tons) }\end{array}$} & \multicolumn{2}{|c|}{$\begin{array}{l}1995 \text { Production } \\
\text { Per Employee (Tons) }\end{array}$} & \multirow{2}{*}{$\begin{array}{l}\text { Average } \\
\text { Annual } \\
\text { Percent } \\
\text { Change } \\
\text { In Average } \\
\text { Product ion } \\
\text { Per Employee } \\
\text { 1985-95 }(3) \\
\end{array}$} \\
\hline & $\begin{array}{l}\text { ICF's } \\
\text { EPA Base } \\
\text { Case }\end{array}$ & $\begin{array}{l}\text { EIA } \\
\text { "Coal Facts" }\end{array}$ & $\begin{array}{l}\text { Average: } \\
\text { EPA } \\
\text { Base Case }\end{array}$ & $\begin{array}{l}\text { Proxmire } \\
\text { Intrastate } \\
\text { Case Impact } \\
\end{array}$ & \\
\hline $\begin{array}{l}\text { Illinois } \\
\text { Indiana } \\
\text { Kentucky } \\
\text { Eastern } \\
\text { Western } \\
\text { Ohjo } \\
\text { Pennsylvania } \\
\text { West Virginia } \\
\text { Northern } \\
\text { Southern }\end{array}$ & $\begin{array}{l}4,500 \\
6,500 \\
4,300 \\
4,100 \\
5,100 \\
4,000 \\
3,000 \\
3,500 \\
4,500 \\
3,000\end{array}$ & $\begin{array}{l}4,300 \\
6,400 \\
4,100 \\
3,800 \\
5,000 \\
4,000 \\
3,200 \\
3,500 \\
n / a \\
n / a\end{array}$ & $\begin{array}{l}5,700 \\
8,700 \\
5,200 \\
4,900 \\
6,600 \\
5,500 \\
4,100 \\
4,600 \\
5,100 \\
4,200\end{array}$ & $\begin{array}{c}7,200 \\
\text { n/a } \\
\text { n/a } \\
4,300 \\
7,700 \\
5,400 \\
6,000 \\
\text { n/a } \\
6,200 \\
4,200\end{array}$ & $\begin{array}{l}2.6 \% \\
2.9 \\
1.9 \\
1.8 \\
2.7 \\
3.2 \\
3.3 \\
2.7 \\
1.4 \\
3.5\end{array}$ \\
\hline
\end{tabular}

Sources: ICF 1987a, 1988b.; EIA 1988.

(a) Based on actual figures, rather than the rounded averages shown in the table.

considerably across producing regions. The first two aspects can be illustrated with an example from the table. Dividing the change in 1995 production by the change in 1995 employment for the Proxmire Intrastate Case in Western Kentucky results in lost production per lost miner of about 7,700 tons per year. The "average" miner in the EPA Base Case produces only about 6,600 tons per year in 1995, which is less than that in the closed mines. The varying rate of change in mining productivity can be seen in the last column of the table.

No assumptions were available concerning the appropriate rate of increase in future marginal labor productivity outside of mining in each state. We assumed that because there was no obvious historical trend in average earnings per worker since 1970 in the coal producing regions (see Appendix Section A.3), there was no reason to adjust the impact estimates for changes in marginal labor productivity. To the extent that there is such a trend, the employment impacts discussed in the next chapter are overstated. For example, if productivity and earnings per worker outside of mining were 
to rise at $1 \%$ per year and the earnings share of output remained constant, then the number of employees affected by a given change in coal production would decline by $1 \%$ per year. This implies a shrinking employment multiplier, as shown in Table 3.3.

\subsection{ECONOMIC MULTIPLIERS USED IN THE STUDY}

Following the steps in the analysis described in the approach section, and adjusting for the effects of labor productivity changes described above, we derived estimates of the economic multipliers to be used in each state in the study. These multipliers are reported in Table 3.4 .

IABLE 3.3. Offsite Employment Multipliers in Coal Mining With and Without Changes in Labor Product ivity: 1986, 1995 and 2000 (a)

\begin{tabular}{|c|c|c|c|c|c|}
\hline Producing Area & $\begin{array}{c}1986 \\
\text { Estimated (b) }\end{array}$ & $\begin{array}{r}\text { Withou } \\
\text { Labor P } \\
1995 \\
\end{array}$ & $\begin{array}{l}\text { hanged } \\
\text { luctivity } \\
2000\end{array}$ & $\begin{array}{c}\text { Offsite Labor } \\
\text { Increases at } \\
1995\end{array}$ & $\begin{array}{l}\text { Productivity } \\
1 \% \text { Per Year } \\
2000 \\
\end{array}$ \\
\hline Illinois & $\begin{array}{l}16.04 \\
16.78\end{array}$ & $\begin{array}{l}16.04 \\
16.78\end{array}$ & $\begin{array}{l}16.04 \\
16.78\end{array}$ & $\begin{array}{l}14.66 \\
15.34\end{array}$ & $\begin{array}{l}13.95 \\
14.60\end{array}$ \\
\hline $\begin{array}{l}\text { Kentucky } \\
\text { Eastern } \\
\text { Western } \\
\text { Ohio } \\
\text { Pennsylvania } \\
\text { West Virginia }\end{array}$ & $\begin{array}{l}17.13 \\
17.13 \\
16.61 \\
16.20\end{array}$ & $\begin{array}{l}17.13 \\
17.13 \\
16.61 \\
16.20\end{array}$ & $\begin{array}{l}17.13 \\
17.13 \\
16.61 \\
16.20\end{array}$ & $\begin{array}{l}15.66 \\
15.66 \\
15.19 \\
14.81\end{array}$ & $\begin{array}{l}14.90 \\
14.90 \\
14.45 \\
14.09\end{array}$ \\
\hline $\begin{array}{l}\text { Northern } \\
\text { Southern }\end{array}$ & $\begin{array}{l}12.25 \\
12.25\end{array}$ & $\begin{array}{l}12.25 \\
12.25\end{array}$ & $\begin{array}{l}12.25 \\
12.25\end{array}$ & $\begin{array}{l}11.20 \\
11.20\end{array}$ & $\begin{array}{l}10.66 \\
10.66\end{array}$ \\
\hline
\end{tabular}

(a) Employment Multiplier = (Total Employees in State Outside of Coa] Mining/Million Dollars Final Demand in 19865 in Coal Mining).

(b) Source: RIMS II System, Regional Economic Analysis Division, Bureau of Economic Analysis, U.S. Department of Commerce, February 26, 1988, adjusted to el iminate direct coal mining jobs. 
TABLE 3.4. Economic Multipliers Used in the Study

\begin{tabular}{|c|c|c|c|c|c|c|c|}
\hline \multirow{3}{*}{ Producing Area } & \multirow{2}{*}{\multicolumn{3}{|c|}{$\begin{array}{r}\text { Reported RIMS I } \\
\text { Multiplier (1986) (a) }\end{array}$}} & \multicolumn{4}{|c|}{ Adjusted Multipliers } \\
\hline & & & & \multicolumn{2}{|c|}{ Earnings } & \multicolumn{2}{|c|}{ Employment } \\
\hline & Output (B) & Earnings (C) & Employment (d) & 1995 & 2000 & $\underline{1995}$ & $\underline{2000}$ \\
\hline $\begin{array}{l}\text { Illinois } \\
\text { Indiana }\end{array}$ & & & $\begin{array}{l}23.0 \\
23.4\end{array}$ & $\begin{array}{l}0.6900 \\
0.5878\end{array}$ & $\begin{array}{l}0.6903 \\
0.5878\end{array}$ & $\begin{array}{l}20.6 \\
21.3\end{array}$ & $\begin{array}{l}21.0 \\
20.7\end{array}$ \\
\hline ent & & & & & & & \\
\hline Eastern & & & 24 & & & 26.0 & 25.3 \\
\hline Wes & & & & & & & \\
\hline Ohio & & & & & & & 21 \\
\hline $\begin{array}{l}\text { Penns } \\
\text { West }\end{array}$ & & 0.6470 & 23 & & 0.7767 & 21.7 & 22 \\
\hline $\begin{array}{l}\text { lest Virginia } \\
\text { Northern }\end{array}$ & & & & & & & \\
\hline Southern & & 0.5246 & & & 0.6598 & 20.3 & \\
\hline
\end{tabular}

(a) Source: RIMS II System, Regional Economic Analysis Division, Bureau of Economic Analysis, U.S. Department of Commerce, February 26, 1988.

(b) Output Multiplier $=$ (Total State Output in 1986\$ / Dollar Final Demand in Coal Mining, in 1986\$). Same for 1995 and 2000 as in 1986.

(c) Earnings Multip) ier = (Total Labor Earnings in State in 1986\$ / Dollar Final Demand in Coal Mining, in 1986\$).

(d) Employment Multiplier $=$ (Total Employees in State / Million Dollars Final Demand in 1986\$). 



\subsection{DETAIL OF IMPACTS}

The purpose of this chapter is to describe in detail the subregional output, employment, and personal income impacts of the changes in coal production analyzed in the study. The first section briefly describes each case; this is followed by an analysis of the impacts of each case on output, personal income and employment in each state in Northern and Central Appalachia and the Midwest.

\subsection{DESCRIPTION OF THE CASES}

The analysis begins with a description of the individual scenarios analyzed in this report. Because the economic analys is is based on direct impacts on coal production operations estimated in a particular way for EPA by ICF, Inc. using their Coal and Electric Utility Model (CEUM), we have paraphrased ICF's description of the key features of each case (ICF 1987a, 1988a). In some cases, other interpretations of the individual pieces of legislation, leading to different impacts, may be possible.

\subsubsection{Proxmire Bill}

The Proxmire Bill (Senate Bill 316--"Acid Deposition Emissions Reduction Act") has as its goal reducing sulfur dioxide emissions from electric utility coal-fired power plants not subject to New Source Performance Standards. The objective is to reduce annual emissions below 1980 levels in the 31 eastern states. The target $\mathrm{SO}_{2}$ reduction levels are about 5 million tons per year (32\%) below 1980 levels by 1995 and 9 million tons per year (58\%) below 1980 levels by the year 2000. Actual reductions from emissions that would have prevailed in the absence of legislation are somewhat greater than this because the targets are based on the 1980 emissions level, whereas emissions are expected to grow in the absence of acid deposition control legislation. We assumed, following the ICF analysis of this case, that the reductions are achieved as follows. First, the 1995 target reduction is set in each state based on emissions resulting from the state's emissions above $2.01 \mathrm{~b} . \mathrm{SO}_{2}$ per million Btu of energy inputs. Second, this statewide reduction is allocated to individual power plants on a plant-by-plant basis. It is assumed that 
allocations can be traded between individual power plants and utility holding companies within the state, but not between states. Third, the target $\mathrm{SO}_{2}$ reduction for the year 2000 is estimated in the same fashion, but the figure of $1.2 \mathrm{lb}$. per million Btu is used. Finally, "cost effective" $\mathrm{NO}_{\mathrm{x}}$ reduction is assumed by the year 2000 . This takes the form that all utility boilers in the 31 eastern states (except those using cyclone, wet bottom, or stokerfired boilers) will install retrofit burner equipment to meet an emission rate of $0.4 \mathrm{lb}$. of $\mathrm{NO}_{\mathrm{x}}$ per million Btu. on tangentially fired boilers and 0.5 1b. of $\mathrm{NO}_{\mathrm{x}}$ per million Btu on wall fired boilers.

\subsubsection{Mitche11 Bill}

The Mitchell Bill (S. Bill 1894) applies to all 48 contiguous states. It is somewhat more ambitious than the Proxmire $B i 11$ in that it attempts to reach more stringent $\mathrm{SO}_{2}$ goals earlier and applies both to utility power plants and to industry. To facilitate the analysis of this bill, ICF assumed that the target reduction in $\mathrm{SO}_{2}$ for the 31 eastern states would be about 4.9 million tons per year in 1995 (5 million nationwide), although the stated goal of the legislation is to achieve this reduction by 1993 . The year 2000 goal is clearly more ambitious than Proxmire- -11.8 million tons per year reduction in the 31 eastern states and $12 \mathrm{million}$ tons nationwide versus 9 million in the Proxmire Bill. Actual reductions from emissions that otherwise would have prevailed are somewhat greater than the targets because, as in the Proxmire Bill, the targets were based on 1980 emissions and emissions were projected to grow in the absence of acid deposition control legisiation.

The reductions are allocated to individual power plants based on an emissions target of 0.9 lb. $\mathrm{SO}_{2}$ per million Btu (for power plants only) and 1980 emission levels as the base. It is assumed that the industrial sector would pursue cost-effective $\mathrm{SO}_{2}$ reduction in the year 2000 and beyond, so ICF's estimate of statewide $\mathrm{SO}_{2}$ reductions required at power plants took account of whether industry emissions in 1995 are higher (due to growth) or lower (due to industrial emissions reduction) than in 1980. After the year 2000 all states are assumed to limit their emissions to the levels prevailing in the year 2000 or to a 30 year/0.9 1b. 1imit. Exemptions are granted for

"smal1" states meeting the standard of $0.9 \mathrm{lb}$. per million Btu and less than 
250,000 total tons of $\mathrm{SO}_{2}$ emitted, as long as 1985 emissions are less than 150,00 tons. This exception proved unimportant to the analysis.

Several features of the Mitchell Bill were not analyzed. These unanalyzed features included: no analysis of the requirement that fuel switching be accomplished within five years; no analysis of the requirement that alT 40-year old stationary sources and all coal-fired utility sources meet New Source Performance Standards (NSPS); and no analysis of the requirement for a 4 million ton reduction in $\mathrm{NO}_{x}$ emissions by 1996.

The Mitchell Bill gives relatively little protection to high sulfur coal despite the stringency of emissions requirements, which seemingly imply the use of stack scrubbers and the resultant possibility of more high sulfur coal being used. However, the stringent emissions requirements in the Mitche11 Bill mean that stack scrubbers must be installed and used in many power plants even when low and medium sulfur coal are burned in order to meet requirements. Plants that do not use scrubbers switch to low sulfur coal. After the year 2000 , older plants, which are affected by the 40 -year NSPS provision must install scrubbers. This enables them to use higher sulfur coal and creates a "rebound" effect after the year 2000 that leads to more production in high sulfur coal production areas. The post-2000 time period is not analyzed in this report, however.

\subsubsection{Million Ton Case (Without Required Scrubbers)}

This case, which is essentially a sensitivity case not based on real legislation, is more ambitious in its short term goals than either the Proxmire $\mathrm{Bill}$ or the Mitchell $\mathrm{Bill}$. The goal in this case is to reduce $\mathrm{SO}_{2}$ emissions by 8 million tons from the 1980 level by 1995, then maintain this level thereafter. The requirements are assumed to apply to all 48 contiguous states and all SIP utility power plants. The significance of the "without required scrubbers" in the title of this case is that there are no specific requirements for installation of stack scrubbers. Utilities are permitted to achieve $\mathrm{SO}_{2}$ reductions in the most cost effective manner; e.g., fue] switching, blending utilization shifts, or scrubbing. As before, because targets are based on 1980 levels and emissions are expected to grow in the absence of controling legislation, the reductions that must be achieved are 
somewhat larger than the target amounts (e.g., about 8.3 million tons nationwide in 1995 vs. the 8 million ton target, with about 7.8 million coming in the 31 eastern states).

In the longer run, this sensitivity test is less ambitious than either the Proxmire or Mitchell $\mathrm{Bill}$, since it requires only 8 million tons $\mathrm{SO}_{2}$ reduction in the year versus 9 million in the Proxmire case and 12 million in the Mitchell case.

\subsubsection{Million Ton Case (With Required Scrubbers)}

This case is a sensitivity case similar to the previously described 8 Million Ton Case, with the additional restriction that stack scrubbers are required on 20 selected large coal-fired power plants with combined generation capacity of about $27 \mathrm{GW}$. This permits higher sulfur coal to be used at some of these plants and results in a considerably smaller reduction in the production of high sulfur coal in Northern Appalachia and the Midwest. As in the previous case, the target level for emission reduction is based on 1980 emissions and emissions are expected to increase in the absence of acid deposition control legislation. Therefore, the reductions in emissions of $\mathrm{SO}_{2}$ in 1995 are projected to be 8.2 million tons (versus 8 million tons relative to the 1980 level) with 7.8 million of that coming from the 31 eastern states.

\subsubsection{Million Ton Case (With Required Scrubbers)}

This sensitivity case is similar to the 8 Million Ton Case (With Required Scrubbers). Twenty power plants are again assumed to be required to have stack scrubbers to reduce $\mathrm{SO}_{2}$ emissions in the years 1995 and beyond. However, the goal in this case is to reduce $\mathrm{SO}_{2}$ emissions only by 6 million tons from its 1980 lever. This requires an actual reduction in the year 1995 of 6.6 million tons nationwide, 6.1 million of this in the 31 eastern states.

\subsubsection{Unexamined Cases}

The selection of cases examined in this study is based on each case's direct effect on coal production (and resulting secondary economic impact) in the three major coal producing regions of interest--Northern Appalachia, Central Appalachia, and the Midwest. Two additional variations of the cases 
were initially examined, then dropped from further consideration. ICF examined a variation of the Proxmire Bill that permitted trading of emission reduction allocations between power plants only within each utility holding company operating within a state and not between utilities. This case did not need to be considered in this study because the coal production impacts (and, therefore, economic impacts) are almost identical to the intrastate trading variation. A variation of the 6 Million Ton Case without required scrubbers did not need to be considered either because the coal production impacts of that case are similar to impacts of other cases (especially the 8 Million Ton Case With Required Scrubbers), so no significant additional information would be added by its analysis.

\subsubsection{Reasons for Selection of Cases}

The reasons for the selection of the cases examined in this report are as follows. The Proxmire Intrastate Case results in the largest impact on year 2000 coal production in Northern Appalachia and Central Appalachia (the Mitche11 Case produces the largest impact in the Midwest) and is the basis for the labor productivity estimates used in this study. It is also based on actual legislation (which some of the cases are not) and therefore contains an important element of realism. It therefore needs to be part of the impact analysis. The 6 Million Ton Case (With Required Scrubbers) consistently produces the smallest impact of any of the cases in both the years 1995 and 2000 and is needed for a lower bound. The 8 Mjlition Ton Case (Without Required Scrubbers) consistently produces the largest 1995 impact. Furthermore, the impact on production actually declines in magnitude in Northern and Central Appalachia between the years 1995 and 2000 (its impact in 2000 is about the same as the Proxmire (ase), which is not true of most of the cases. The 8 Million Ton Case (With Required Scrubbers) could have been dropped to minimize the number of cases, since its impacts always $1 \mathrm{je}$ between those of two other cases; however, the differences in impact between this cases and 8 Million Ton Case (Without Required Scrubbers) requirements gives a clear sensitivity test of the importance of stack scrubbers to both high and low sulfur coal mining regions. Finally, the Mitchell Case is analyzed becau se it is the high impact case in the Midwest in the year 2000 and because it demonstrates the relatively modest impacts on coal mining of very stringent 
sulfur emission controls in some of the regions. This modest impact occurs because both medium and low sulfur coal emissions must be scrubbed if the regulations on emissions are tight enough, thereby reducing the amount of regulation-induced switching to low sulfur coal.

To put the changes in coal production in these scenarios in perspective, it may be helpful to compare them to annual fluctuations in coal production resulting from year-to-year changes in the national and international coal markets. According to EIA figures (EIA 1988), between 1980 and 1986, the average absolute value of year-to-year fluctuations (positive or negative) in coal production in the six state area discussed in this study was about 32 million tons. The Proxmire case results in a relative decrease equal to about half of this amount in 1995 and about twice this amount in the year 2000. In the most-affected state of Illinois, the regulation-induced decrease was twice the average annual fluctuation in 1995, and 7.5 times the annual fluctuation in the year 2000. Because the changes in the Proxmire Case are cumulative over 15 to 20 years, however, even in Illinois the impacts represent annual differences in production equal smaller in size than annual changes in production historically induced by market forces.

\subsection{DESCRIPTION OF SELECTED ECONOMIC IMPACTS}

Impacts on the level of regional economic activity, as measured by out-

put, employment, and personal income, can be classified as direct (onsite) impacts, secondary (offsite) impacts, and total impacts, which are the sum of the first two categories. This section summarizes these three types of economic impacts due to the effects of acid deposition control legislation on the coal industry in each of the 6 states in the study. The effects of the Mitchell and Proxmire Bills are very similar in the year 1995; however, after that the paths of impacts diverge, with generally smaller local impacts in the Mitchell case. This occurs even though the overall impacts in the six state area are greater in the Mitchell Case. It occurs because although, as shown in Chapter 2.0, the overall change in coal production is greater in the Mitchell Case (e.g., 75 million tons in the year 2000 vs. 67 million tons in the Proxmire Case), several of the individual production areas show larger changes in production in the Proxmire Case. These larger changes in some 
production areas, however, are balanced by Targer changes in the opposite direction in other areas, leading to a smaller net regional impact.

\subsubsection{Direct Impacts}

For example, Table 4.1 shows that in the year 2000, Illinois, Pennsylvania, and ohio are projected to have 13,800 fewer jobs in coal mining than in the absence of acid deposition control in the Proxmire case. (6,900 plus 2,300 plus 4,600). About half of these "losses" occur in Illinois, and represent about $46 \%$ of the jobs in coal mining in I1linois in 1986. Kentucky gains about 4,000 jobs $(5,400$ gained in Eastern Kentucky minus 1,400 lost in Western Kentucky) over the forecasted situation with no acid deposition control. This represents an increase equal to about $11 \%$ of 1986 employment in the industry. West Virginia gains $2,900(4,100$ increase in Southern West Virginia, minus 1,200 decrease in Northern West Virginia). This is about $8 \%$ of the 1986 employment level. In the Mitchell case, the combined losses of coa] employment opportunities in Illinois, Pennsylvania and Ohio tota] 11,700 , but the net gains in Kentucky $(1,000)$ and West Virginia $(1,600)$ are also smaller. Indiana is slightly worse off under the Mitchell scenario.

The biggest negative direct impacts on coal mining under both bills are concentrated in the states having the biggest economies, while the biggest positive impacts are in the smallest economies (Kentucky and West Virginia) and are associated with positive production changes in those parts of those states generally regarded as economically poorer--Eastern Kentucky in particular. In all the states in question, the direct impacts are less than onehalf of one percent of total 1986 employment. Kentucky fares somewhat better under the Proxmire Bill, with greater job gains in the east and about the same job losses in the western part of the state. Under Proxmire, Northern West Virginia suffers greater job and income losses, but the southern part of the state offsets this with greater gains. There is little difference between the bills in Illinois, the worst-hit state, but both Pennsylvania and Ohio are slightly better off under the Mitchell Bill.

The 8 Million Ton Case (Without Required Scrubbers) provides an estimate of shorter run (1995) impacts of accelerated acid deposition control, since it requires that $60 \%$ more sulfur emissions be eliminated than under either 
TA8LE 4.1. Selected Direct Economif Impacts on the Coal Industry of Acid Deposition Control in Six Coal Producing States (a)

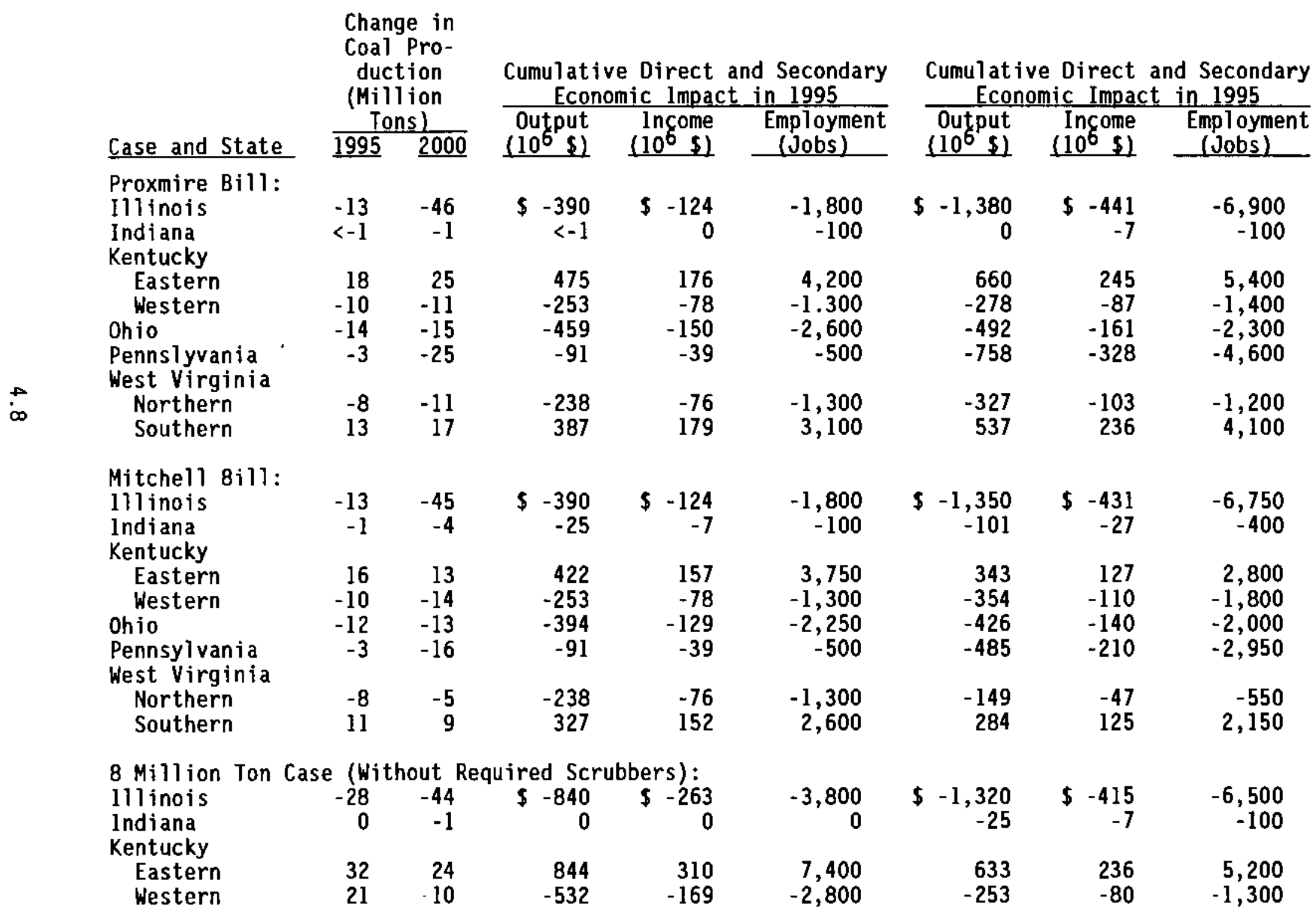


IABLE 4.1. (contd)

\begin{tabular}{|c|c|c|c|c|c|c|c|c|}
\hline \multirow[b]{2}{*}{ Case and State } & \multirow{2}{*}{\multicolumn{2}{|c|}{$\begin{array}{l}\text { Change in } \\
\text { Coal Pro- } \\
\text { duction } \\
\text { (Million } \\
\text { Tons) } \\
\end{array}$}} & \multicolumn{3}{|c|}{$\begin{array}{l}\text { Cumulative Direct and Secondary } \\
\text { Economic Impact in } 1995 \\
\end{array}$} & \multicolumn{3}{|c|}{$\begin{array}{c}\text { Cumulative Direct and Secondary } \\
\text { Economic Impact in } 1995\end{array}$} \\
\hline & & & $\begin{array}{r}\text { Output } \\
\left(10^{6} \$\right)\end{array}$ & $\begin{array}{l}\text { Income } \\
\left(10^{6} \$\right)\end{array}$ & $\begin{array}{l}\text { Employment } \\
\text { (Jobs) }\end{array}$ & $\begin{array}{r}\text { Output } \\
\left(10^{6} \$\right)\end{array}$ & $\begin{array}{r}\text { Income } \\
\left(10^{6} \$\right)\end{array}$ & $\begin{array}{l}\text { Employment } \\
\text { (Jobs) }\end{array}$ \\
\hline $\begin{array}{l}\text { Ohio } \\
\text { Pennslyvania } \\
\text { West Virginia }\end{array}$ & $\begin{array}{r}-27 \\
-6\end{array}$ & $\begin{array}{l}-12 \\
-20\end{array}$ & $\begin{array}{l}-886 \\
-182\end{array}$ & $\begin{array}{r}-295 \\
-79\end{array}$ & $\begin{array}{l}-5,100 \\
-1,000\end{array}$ & $\begin{array}{l}-394 \\
-606\end{array}$ & $\begin{array}{l}-126 \\
-264\end{array}$ & $\begin{array}{l}-1,800 \\
-3,700\end{array}$ \\
\hline $\begin{array}{l}\text { Northern } \\
\text { Southern }\end{array}$ & $\begin{array}{r}-16 \\
23\end{array}$ & $\begin{array}{l}-9 \\
16\end{array}$ & $\begin{array}{r}-476 \\
727\end{array}$ & $\begin{array}{r}-145 \\
318\end{array}$ & $\begin{array}{r}-2,500 \\
5,500\end{array}$ & $\begin{array}{r}-268 \\
506\end{array}$ & $\begin{array}{r}-86 \\
225\end{array}$ & $\begin{array}{r}-1,000 \\
3,900\end{array}$ \\
\hline $\begin{array}{l}8 \text { Million Ton Case } \\
\text { Illinois } \\
\text { Indiana } \\
\text { Kentucky }\end{array}$ & $\begin{array}{l}\text { (With } \\
-12 \\
0\end{array}$ & $\begin{array}{l}\text { Requ } \\
-29 \\
-1\end{array}$ & $\begin{array}{r}\text { ed Scrubb } \\
\$-360 \\
0\end{array}$ & rs): $\begin{array}{r} \\
\$-111 \\
0\end{array}$ & $\begin{array}{r}-1,600 \\
0\end{array}$ & $\begin{array}{r}5 \\
-870 \\
-25\end{array}$ & $\begin{array}{r}-275 \\
-7\end{array}$ & $\begin{array}{r}-4,300 \\
-100\end{array}$ \\
\hline $\begin{array}{l}\text { Eastern } \\
\text { Western } \\
\text { Ohio } \\
\text { Pennslyvania } \\
\text { West Virginia }\end{array}$ & $\begin{array}{r}12 \\
-9 \\
-12 \\
-3\end{array}$ & $\begin{array}{l}12 \\
-7 \\
-5 \\
-9\end{array}$ & $\begin{array}{r}317 \\
-228 \\
-394 \\
-91\end{array}$ & $\begin{array}{r}117 \\
-72 \\
-127 \\
-31\end{array}$ & $\begin{array}{r}2,800 \\
-1,200 \\
-2,200 \\
-400\end{array}$ & $\begin{array}{r}317 \\
-177 \\
-164 \\
-273\end{array}$ & $\begin{array}{r}118 \\
-56 \\
-56 \\
-121\end{array}$ & $\begin{array}{r}2,600 \\
-900 \\
-800 \\
-1,700\end{array}$ \\
\hline $\begin{array}{l}\text { Northern } \\
\text { Southern }\end{array}$ & $\begin{array}{r}-7 \\
9\end{array}$ & $\begin{array}{r}-4 \\
8\end{array}$ & $\begin{array}{r}-208 \\
284\end{array}$ & $\begin{array}{l}-64 \\
122\end{array}$ & $\begin{array}{r}-1,100 \\
2,100\end{array}$ & $\begin{array}{r}-119 \\
253\end{array}$ & $\begin{array}{r}-34 \\
115\end{array}$ & $\begin{array}{r}-400 \\
2,000\end{array}$ \\
\hline $\begin{array}{l}6 \text { Million Ton Case } \\
\text { Illinois } \\
\text { Indiana } \\
\text { Kentucky }\end{array}$ & $\begin{array}{l}\text { (With } \\
-6 \\
0\end{array}$ & $\begin{array}{l}\text { Requ } \\
-29 \\
0\end{array}$ & $\begin{array}{r}\text { ed Scrubb } \\
5-180 \\
0\end{array}$ & s): $\begin{array}{r}-55 \\
\\
\end{array}$ & $\begin{array}{r}-800 \\
0\end{array}$ & $\$-870$ & $\$-250$ & $\begin{array}{r}-3,200 \\
0\end{array}$ \\
\hline $\begin{array}{l}\text { Eastern } \\
\text { Western } \\
\text { Ohio } \\
\text { Pennslyvania } \\
\text { West Virginia }\end{array}$ & $\begin{array}{r}6 \\
-4 \\
-6 \\
-1\end{array}$ & $\begin{array}{r}8 \\
-5 \\
-2 \\
-4\end{array}$ & $\begin{array}{r}158 \\
-101 \\
-197 \\
-30\end{array}$ & $\begin{array}{r}59 \\
-36 \\
-64 \\
-16\end{array}$ & $\begin{array}{r}1,400 \\
-600 \\
-1,100 \\
-200\end{array}$ & $\begin{array}{r}211 \\
-127 \\
-66 \\
-121\end{array}$ & $\begin{array}{r}77 \\
-43 \\
-21 \\
-43\end{array}$ & $\begin{array}{r}1,700 \\
-700 \\
-300 \\
-600\end{array}$ \\
\hline $\begin{array}{l}\text { Northern } \\
\text { Southern }\end{array}$ & $\begin{array}{r}-4 \\
4\end{array}$ & $\begin{array}{r}-2 \\
5\end{array}$ & $\begin{array}{r}-119 \\
126\end{array}$ & $\begin{array}{r}-35 \\
58\end{array}$ & $\begin{array}{r}-600 \\
1,000\end{array}$ & $\begin{array}{l}-60 \\
158\end{array}$ & $\begin{array}{r}-17 \\
75\end{array}$ & $\begin{array}{r}-200 \\
1,300\end{array}$ \\
\hline
\end{tabular}

(a) All dollar figures are reported in 1986 constant dollars. 
the Mitchell Bill or the Proxmire Bill. While there are significant intrastate transfers of mining activity in both West Virginia (north to south) and Kentucky (west to east) in this case, both states' coal industries generaliy benefit significantly from accelerated removal of sulfur emissions. The states of Illinois and Ohio bear the primary additional negative economic impacts of accelerated emissions reduction.

If required scrubbing is introduced, as it is in the 8 Million Ton Case (With Required Scrubbers), the negative economic impacts on the Illinois and Ohio coal industries are cut in half. Conversely, so are the positive benefits in Kentucky and West Virginia. For example, Eastern Kentucky coal jobs increase by only 2800 instead of 7400 . This is because less coal switching is required to meet the sulfur reduction goals when scrubbers are required.

The U.S. economy is forecasted to grow between 1995 and 2000 . To maintain the 8 Million Ton reduction in sulfur emissions in the face of this growth requires additional changes in coal production. The positive impact in Eastern Kentucky coal mining jobs and income decreases between 1995 and 2000 , as less coal is used from that production area to maintain the 8 million ton reduction in sulfur emissions when the size of the U.S. economy grows. Relatively less mining takes place in Pennsylvania and in Illinois between 1995 and 2000, as these areas bear the brunt of high-sulfur coal mining penalties associated with U.S. economic growth and fixed emissions targets.

The impacts in the 6 Million Ton Case shown in Table 4.1 illustrate roughly what would happen if: 1) only the short-term sulfur emission goals of the Proxmire and Mitchell Bills were implemented and 2) a large portion of the reduction were achieved with scrubbers rather than by coal switching. In 1995, with slightly more stringent goals than either Proxmire or Mitchell Case, the 6 Million Ton Case shows about one third to one half the economic impact on coal mining (either positive or negative). In the year 2000 , the importance of scrubbers to the Mitchell Bill is demonstrated by the fact that (except for Ohio and Pennsylvania) the 6 Million Ton Case shows impacts of roughly half the size of those the Mitchell Case for roughly half the sulfur 
removal goal. The Proxmire case, which relies less on scrubbing, shows sulfur removal goals only 50\% larger than the 6 Million Ton Case, but impacts on the coal sector at least three times as large or larger.

\subsubsection{Secondary (Offsite) Impacts}

Table 4.2 illustrates the secondary or offsite impacts on output, personal income, and employment associated with the changes in coal production in each state and producing area in the various acid deposition control cases. Because of the type of impact methodology used in this study, the economic impacts are roughly proportional to changes in coal production. For example, the states of Illinois, Pennsylvania, and Ohio show 42,500 jobs lost in the year 2000 outside the coal sector as a result of lower activity in the coal mining sector in these states under the Proxmire Bill. About half of these losses occur in Illinois, where about half of three states' coal production losses occur. The states of Kentucky and West Virginia gain about 6,500 jobs and 2,600 jobs, respectively, and Indiana is only slightly affected. The largest negative secondary impacts occur in the states with the largest economies while the net gains occur in those states having the smallest economies and in the economically poorest parts of those states. As with the direct impacts, the offsite employment impacts amount to less than one half of one percent of total employment in the respective states, a)though they may represent quite significant proportions of the workforce in individual coal mining counties and communities.

Kentucky and West Virginia show higher offsite output, income, and employment under the Proxmire Bill than under the Mitchell Bill, while the reverse is true of Ohio, Indiana, and Pennsylvania. Illinois sees roughly equal negative offsite impacts under either bill.

Under ejther the Mitchell Bill or the Proxmire Bill, offsite income and employment impacts more than triple in magnitude between 1995 and 2000 in some of the states (notably Illinois and Pennsylvania), even though the sulfur emissions goals increase by at most a factor of two. These changes are in proportion to the relative changes in coal production in each producing area because the underlying economic models are linear models. 

IABLE 4.2. Selected Offsite Economic lmpacts of Acid Deposition Control in Six Coal
Producing States (a)

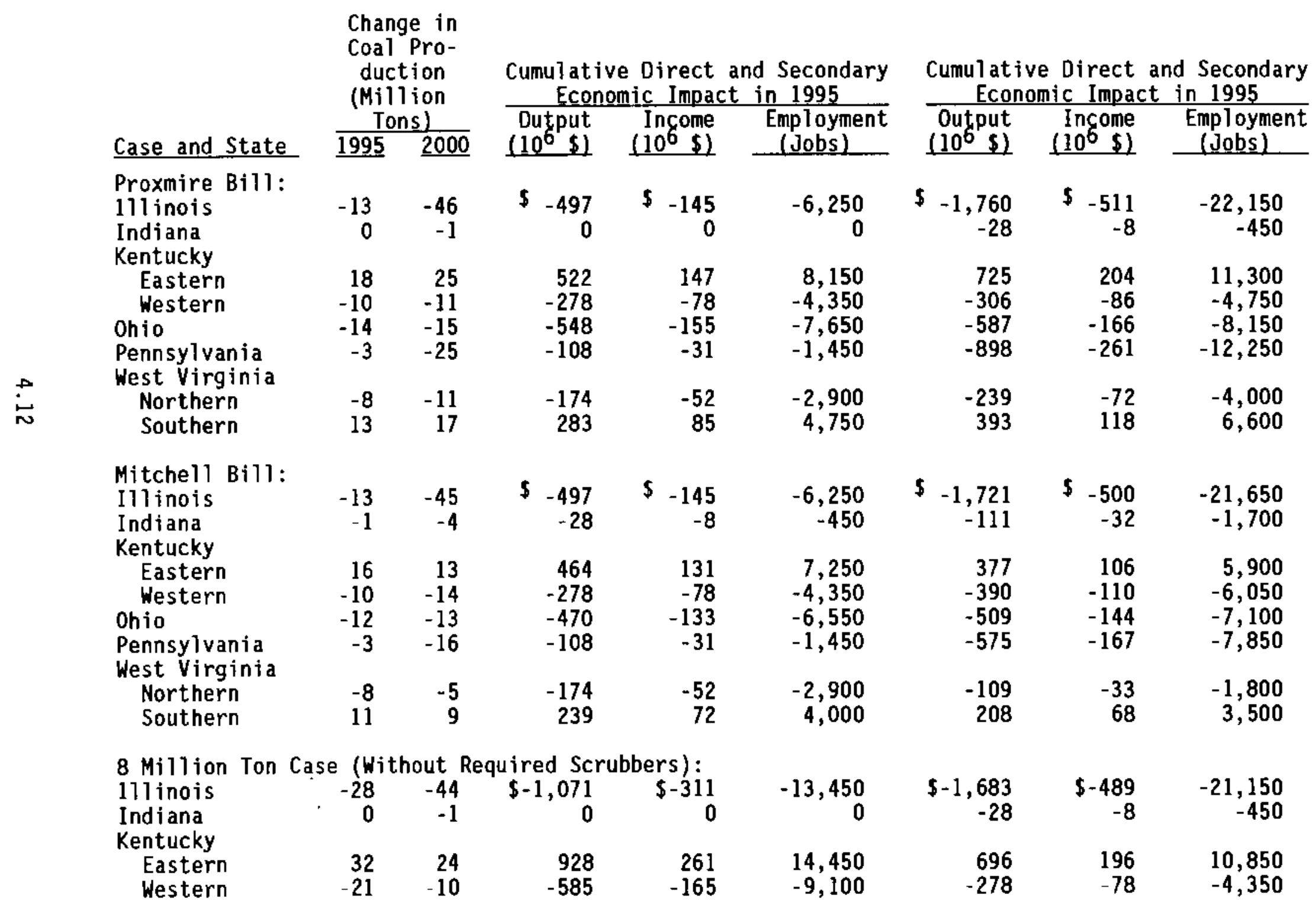


TABLE 4.2. (Contd)

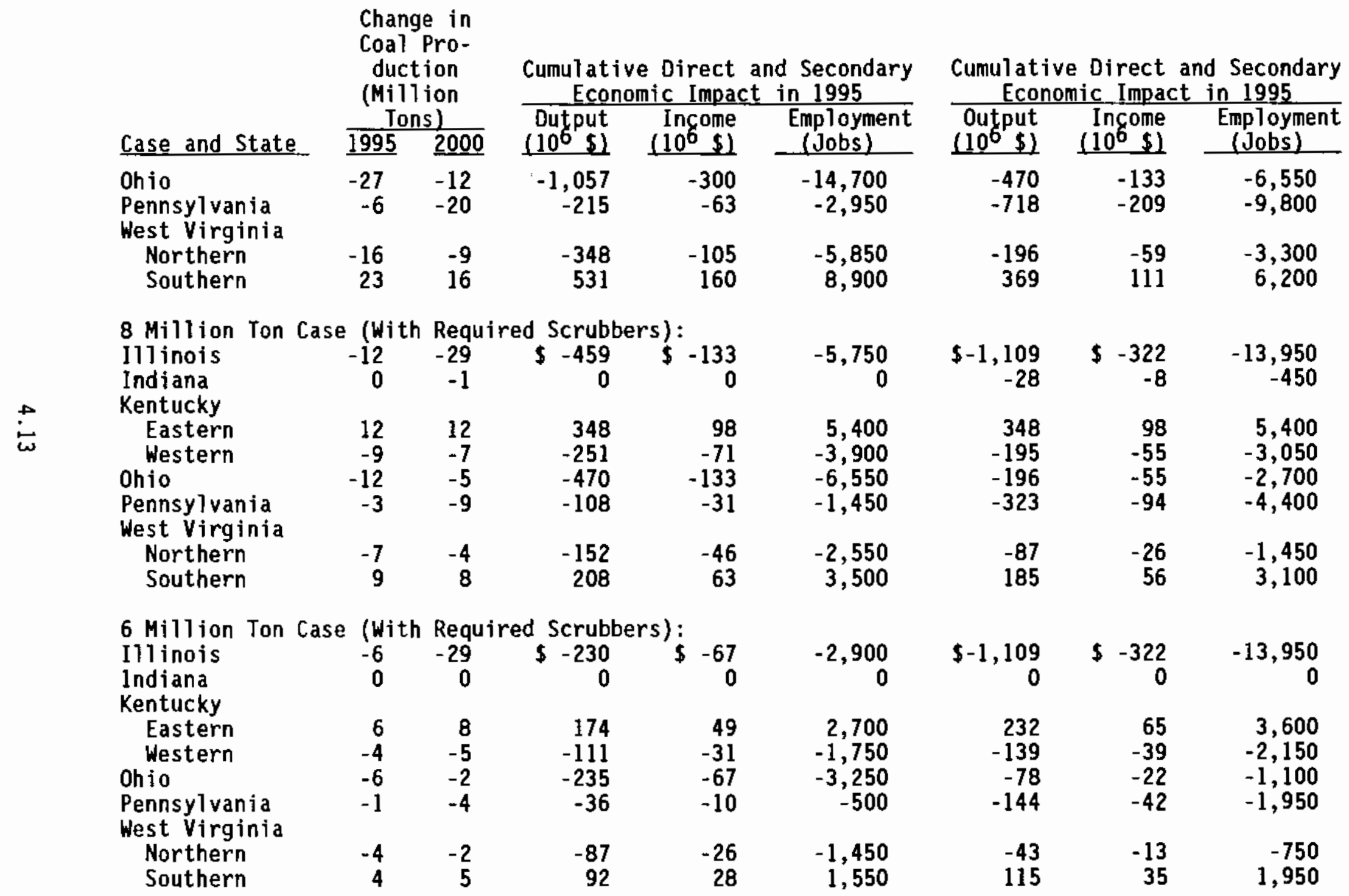

(a) All dollar figures are reported in 1986 constant dollars. 
However, the multipliers underlying these impact estimates are subject to uncertainty, because the actual offsite effects might not be proportional to changes in coal production. Therefore, both magnitude of these changes and their geographical distribution should be viewed with caution.

In Eastern Kentucky and Southern West Virginia, the positive economic impacts in the Mitchell Case decline between 1995 and 2000 , but so do the negative impacts in Northern West Virginia.

As might be expected based on relative coal production and onsite impacts, the offsite economic impacts in the 8 Million Ton Case (Without Required Scrubbers) tend to be double those of either the Proxmire or Mitchell Case in the year 1995. They are similar in magnitude to the impacts of the Proxmire Bill in the year 2000 in most of the producing areas. Also as might be expected from the relative changes in coal production, the 6 Million Ton Case costs roughly one third of the offsite jobs and income that the Proxmire case costs in 1995, but only generates about one third the number of offsite jobs in the areas benefitted.

Comparing the two 8 Million Ton cases, we note that the changes in offsite employment and income are roughly half as large when scrubbing is required as when it is not.

\subsubsection{Direct Plus offsite Economic Impacts}

Table 4.3 shows the direct plus offsite impacts on the levels of output, personal income, and employment for the coal production areas of the six coal producing states in the study for the years 1995 and 2000 in each of the five coal production scenarios. These economic impacts are roughly proportional to the corresponding changes in coal production. The table shows that the Proxmire Bill's economic impacts through coal production are greater (in both positive and negative directions) than those under the Mitchell Bill in individual producing states, even though the latter bill contemplates more ambitious sulfur emissions control. For example, the Proxmire Bill costs 56,000 jobs in the year 2000 in the three states of I1linois, Pennsylvania, and Ohio, while it adds a net 10,000 jobs in Kentucky and 5,000 in West Virginia. Almost half the job losses are again in 111 inois. Indiana is almost unaffected. Only in West Virginia $(+0.75 \%)$ and Kentucky $(+0.60 \%)$ are the employment 
TABLE 4.3. Selected Direct Plus Offsite Economic 1mpacts of Acid Deposition Control in Six Coal Producing States(a)

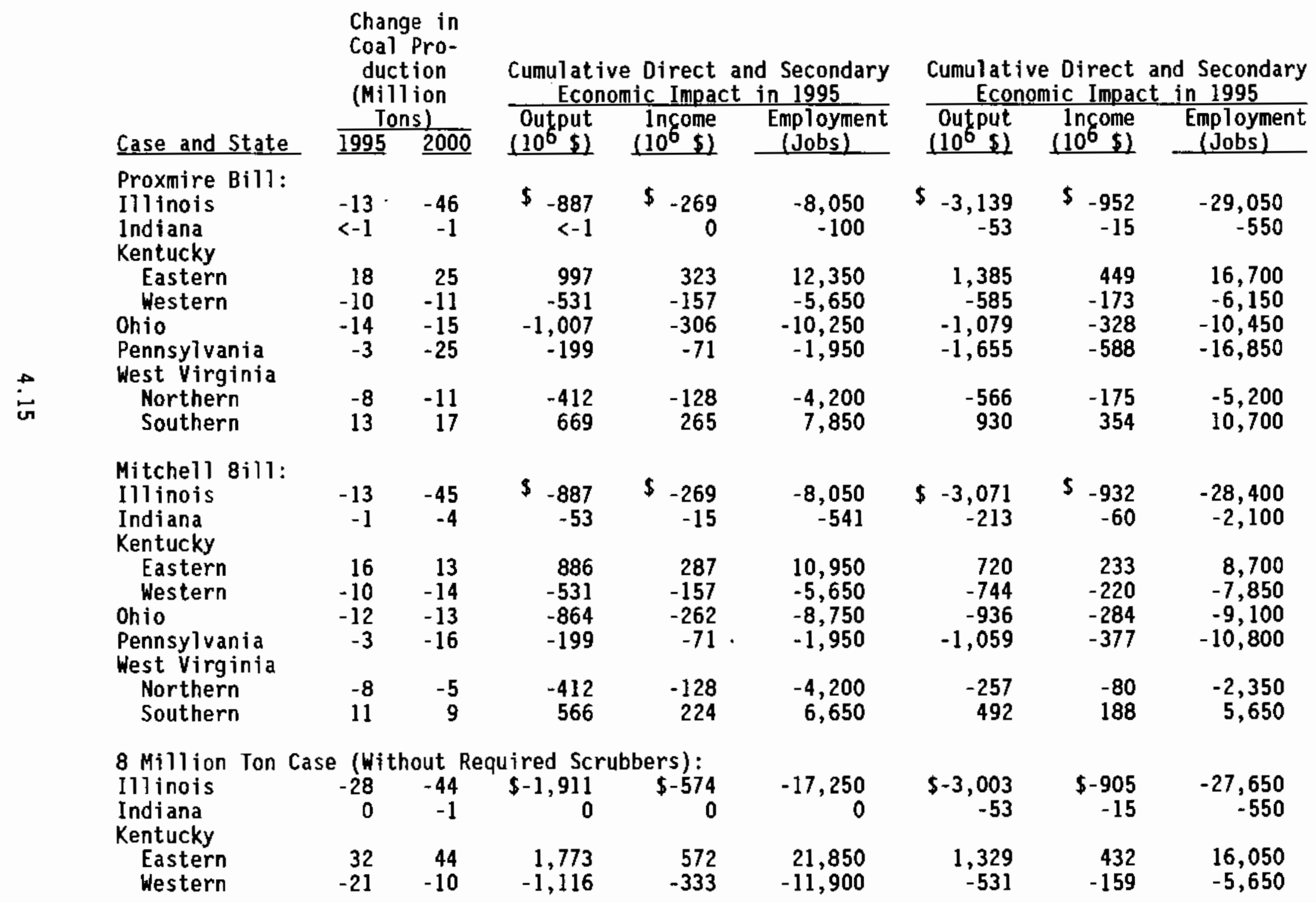


FIGURE 4.3. (Contd)

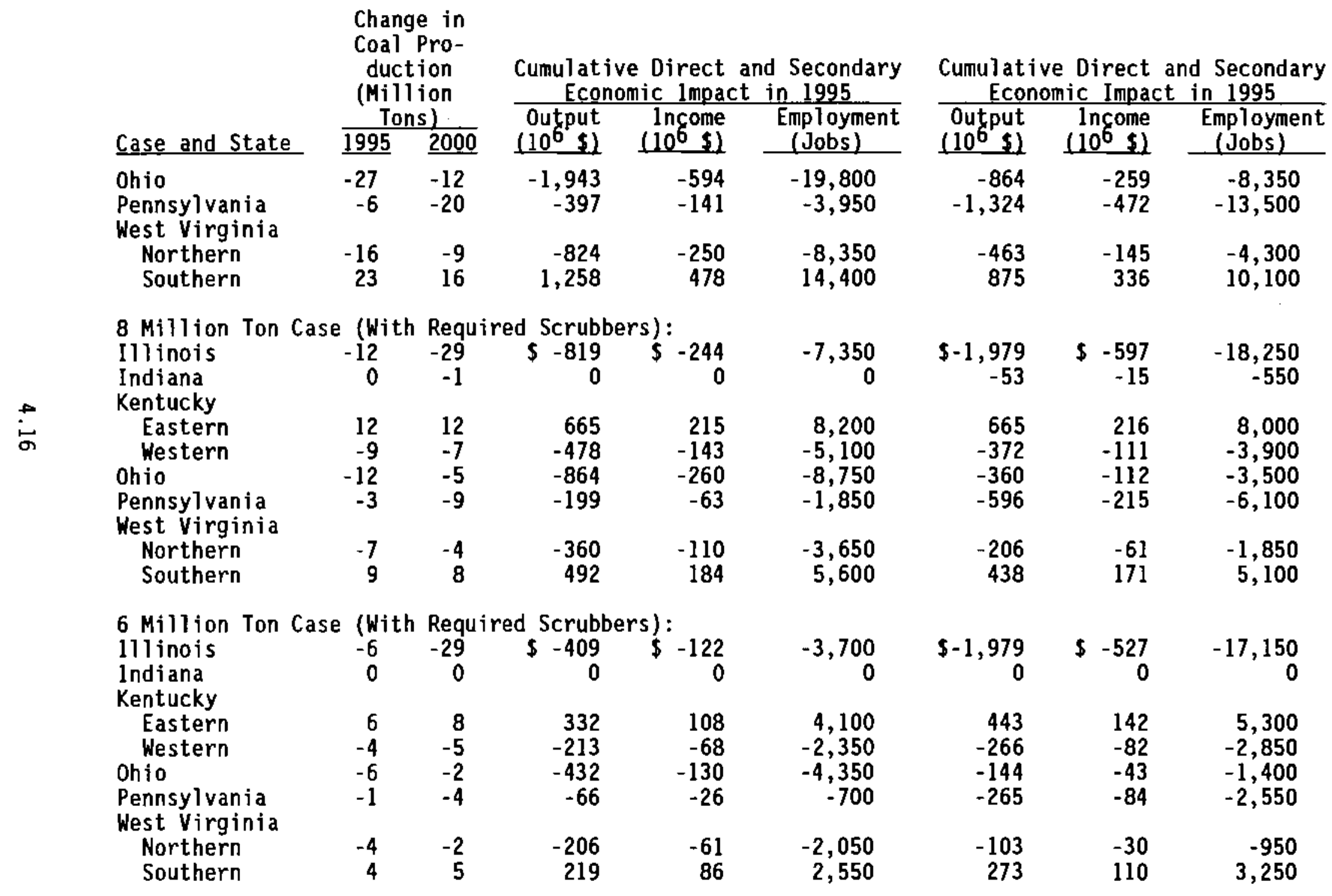

(a) All dollar figures are reported in 1986 constant dollars. 
impacts as 1.arge as one half of one percent of 1986 total state employment. As before, the impacts may be more important in specific coal mining counties and communities. The Mitche 11 Bill costs fewer jobs--48,000--in Illinois, Pennsyivania and 0 hio in the year 2000, but shows a much smaller increase in employment in Kentucky (850 jobs) and West Virginia $(3,000)$. Indiana loses 2,100 jobs in the Mitchell Case, and only about 550 in the Proxmire Case. Because both the onsite and offsite impacts show the same distribution across producing areas, years, and cases, the total impacts also show this same distribution. The 8 Million Ton Case (Without Required Scrubbers) has roughly twice the total impact in 1995 and about the same as the Proxmire Bill in the year 2000. The 8 Million Ton Case (With Required Scrubbers) has similar impacts to the Proxmire Case in the short run: however, its impacts are considerably (one-third to one-half) lower than the Proxmire Case in the year 2000. 
. 


\subsection{REFERENCES}

Arthur D. Little, Inc. Economic Impacts of Alternative Acid Rain Control Strategies. Final Report to Consolidation Coal Company, Reference 50277.

Arthur D. Little, Energy Ventures Analysis, Inc. Cambridge, Massachusetts.

Bourque, P. J., R. S. Conway, and C. T. Howard. 1977. The Washington Projection and Simulation Mode 1: An Input-Output Econometric Model of Washington State. Graduate School of Public Administration, University of Washington, Seattle, Washington.

Cartwright, J. V., R. M. Beemiller, and R. D. Gustely. 1981. Regional Input-Output Modeling System: Estimation, Evaluation, and Application. U.S. Government Printing Office, Washington, D.C. National Technical Information Service, Springfield, Virginia.

Conway, R. S. 1979. "Simulation Properties of a Regional Interindustry Econometric Model. Papers, Regional Science Association 43 (1979):45-47.

Etter, C. L., D. M. Violette, and L.S. Rathbun. March 21, 1988. Estimated Cost Impacts of Senate Bil] 1894. Title II. RCG/ Hagler, Bailly, Inc., Boulder, Colorado.

Greenstreet, D. 1987 (Greenstreet 1987a). "Constructing an Interregional Commodity-by-Industry Input-Output Model." Research Paper 8713, Regional Research Institute, West Virginia University. Presented at the 34 th North American Meetings of the Regional Science Association, November 6-8, 1987.

Greenstreet, D. September 1987 (Greenstreet 1987b). A Users Guide to the 1982 West Virginia Input-Output Model. Center for Economic Research, Regional Research Institute, West Virginia University, Morgantown, West Virginia.

ICF, Inc. July 6, I987 (ICF 1987a). "Preliminary Analysis of the Proxmire Bill Assuming Intrastate Trading and Assuming Emissions Trading Restricted Within Utility Holding Companies." Letter Report to Paul Schwengels, Rob Brenner and Brian McClean, Environmental Protection Agency from Bruce Braine and Richard Stuebi, ICF, Inc., I860 K Street, N.W., Washington, D.C.

ICF, Inc. September 21, 1987 (ICF 1987b). "Summary Forecasts from the Analysis of the Six and Eight Million Ton Cases. "Letter Report to Nancy Kete, Environmental Protection Agency from Bruce Braine and Richard Stuebi, ICF, Inc., $1860 \mathrm{~K}$ Street, N.W., Washington, D.C.

ICF, Inc. March, 1988 (ICF 1988a). Preliminary Analysis of the Mitchell Bill (S.1894). Report prepared for the Environmental Protection Agency by ICF, Inc., $1860 \mathrm{~K}$ Street, N.W., Washington, D.C. 
ICF, Inc. May 5, 1988 (ICF 1988b). "State Level Coal Production Forecasts for the Proxmire Bi11." Letter Report to Paul Schwengels, Environmental Protection Agency from Bruce Braine and Robin Langdon, ICF, Inc., $1860 \mathrm{~K}$ Street, N.W., Washington, D.C.

Mattas, K., A. Pagoulatos, and D. L. Debertin. 1984. Building Input/Output Models Using Non-Survey Techniques: An Application to Kentucky. Southern Rural Development Center and the Department Agricultural Economics, University of Kentucky, Lexington, Kentucky.

Pagoulatos, A. and K. R. Ansche11. 1981. "An I-0 Study of the Economic Structure of Appalachian Kentucky." Growth and Change, October 1981.

Ro, Y. K. 1982. Environmental Requlation and the Regional Economy: An Input-Output Analys is of the Ohio Coal Mining Region. Ph.D. Dissertation, The Ohio State University, Columbus, Ohio.

U.S. Department of Energy, Energy Information Administration. 1988. Coal Production 1986. DOE/EIA-0118(86). U.S. Government Printing Office, Washington, D.C. 
APPENDIX A

METHODOLOGICAL_ISSUES 


\section{APPENDIX A}

\section{METHODOLOGICAL ISSUES}

This appendix discusses several methodological issues raised in the main report and provides additional documentation for several of the assumptions implicitly or explicitly made in the analysis. Among these assumptions are: 1) that equal sized changes in the level of coal mining activity in different areas within a given state have equal impacts on statewide economic activity; 2) that changes in the level of coal mining activity in different states do not affect the level of economic activity in adjoining states; 3 ) that there will be no changes in the average productivity of workers outside the coal mining sector before the year 2000 that will be reflected in state average real wages; 4) that changes in the level of economic activity in a state do not affect the level of government spending; 5) that RIMS II multipliers are the most accurate available for each state. The following sections discuss each assumption in turn.

\section{A.1 INTRASTATE DIFFERENCES IN ECONOMIC MULTIPLIERS}

Two of the states discussed in the main report have been subdivided into coal mining areas. Kentucky is divided into eastern and western areas and West Virginia is divided into northern and southern areas. No comparable division has been made in the RIMS II multipliers. In each state it is implicitly assumed that changes in coal mining activity in either part of the state has the same statewide impact. This is not likely to be literally true, but may be superior to using local multipliers from RIMS Il, which do not account for economic impacts of one area within a state on other areas within the same state.

While it is possible to obtain multipliers from the RIMS II system for any grouping of counties, RIMS II local multipliers would not provide information on the statewide effects of substate economic changes, only impacts within the local substate area. Implicitly, there is no intrastate trade. Consequently, in the RIMS II system the sum of local economic impacts

A. 1 
associated with increases in final demand for coal of $\$ 1$ million each in both Eastern and Western Kentucky would be less than the statewide economic impact of $\$ 2$ million in statewide final demand for coal unless the statewide multiplier is used for both areas.

To obtain an indication of the differences between coal mining in Eastern and Western Kentucky and Northern and Southern West Virginia, we constructed Table A.l, which describes the differences between Eastern and Western Kentucky. In Kentucky, the eastern coal production area shows a higher percentage of underground mines and lower annual production per miner than does the western part of the state. In other words, the eastern coa] producing region is relatively labor intensive and less productive on a per capita basis. If the usual regional economic relationships apply, this probably means that a loss of a \$1 million in final demand for Eastern Kentucky coal will cost more direct jobs than would a comparable loss of demand for Western Kentucky coal. The relative size of impacts in the state's support sector are more difficult to judge. On the one hand, high capital intensity could imply that Western Kentucky mines may buy more goods and services from other businesses per million dollar change in coal demand. On the other hand the capital intensive Western Kentucky operations may be more likely to require specialized mining equipment that is supplied from outside of the state, implying a smaller indirect effect per dollar of final demand. We also note that if the Western Kentucky miners are more productive on average, they are probably better paid than Eastern Kentucky miners and generate relatively more secondary economic activity. This could offset to some degree the greater direct effects on statewide employment of the relatively high labor intensity associated with Eastern Kentucky mining. On balance, one

TABLE A.1. Substate Differences in Coal Mining in Coal Producing Areas of Kentucky, 1986

\begin{tabular}{|c|c|c|c|c|c|}
\hline \multirow{2}{*}{$\begin{array}{l}\text { State and Producing } \\
\text { Area }\end{array}$} & \multicolumn{2}{|c|}{$\begin{array}{l}\text { Percent of Mine } \\
\text { Output }\end{array}$} & \multicolumn{3}{|c|}{$\begin{array}{l}\text { Annual Production } \\
\text { Per Miner }(\$ 1986) \\
\end{array}$} \\
\hline & Surface & Underground & Surface & Underground & Average \\
\hline $\begin{array}{l}\text { Eastern Kentucky } \\
\text { Western Kentucky } \\
\text { Kentucky Total }\end{array}$ & $\begin{array}{l}40.4 \% \\
48.2 \\
42.5\end{array}$ & $\begin{array}{l}59.6 \% \\
51.7 \\
57.5\end{array}$ & $\begin{array}{r}\$ 136,000 \\
216,000 \\
153,000\end{array}$ & $\begin{array}{r}\$ 101,000 \\
125,000 \\
106,000\end{array}$ & $\begin{array}{r}\$ 113,000 \\
158,000 \\
122,000\end{array}$ \\
\hline
\end{tabular}


cannot say with any certainty which subarea would have the higher multiplier. Similar differences also appear between Northern and Southern West Virginia, but again it is not obvious which area should have the larger multiplier.

\section{A.2 INTERSTATE TRADE EFFECTS}

The impact of changing geographical patterns of coal production within the Appalachian and Midwest coal regions may be less than forecasted by state input-output models such as RIMS II because many of the forecasted impacts are a result of reduced sales by firms supporting the coal industry with goods and services, the so-called "indirect effect". In the RIMS II models, reduced production of coal in ohio mechanically leads to a proportional reduction in the sales by firms in ohio that support the coal industry, and thus to further reductions in economic activity. In reality, however, businesses actually may be much more flexible than the models depict them. If, for example, the Kentucky coal industry expands at the same time the ohio coal industry shrinks, the ohio firms supporting the coal industry may simply make up for lost ohio sales by increasing their sales in Kentucky. Thus there might be no net indirect effect on economic output or employment in either state. If this hypothetical reorientation in sales occurred, RIMS II would overstate the negative total economic impact of a reduction in coal mining activity in 0 io and also overstate the positive impact in Kentucky.

How large might the potential overstatement be? To estimate this, we secured $39 \times 39$ sector input-output tables from the RIMS II system and decomposed the multiplier response. Table A.2 shows the reported output response per million dollars of output for 39 row industries for the six states, and adjusted output response to the value it would have if sales of intermediate goods sales were unaffected. For most of the states, the jobs indirectly accounted for by coal mining procurements comprise about $33-35 \%$ of the total. In West Virginia, this percentage is only $27 \%$. Consequently, if regional supplying businesses are unaffected by mine closures (that is, if they geographically reorient their direct sales to the coal industry when some mines close and others expand production), the negative and positive impacts could be about one-quarter to one-third smaller than stated in the text of this report. 
TABLE A.2. Adjustments to the RIMS II State Economic Muitipliers with Limited Indirect Response (a)

Change Output Multiplier Income Multiplier Employment Multiplier State or Producing As Limited As Limited As Limited Area Reported Indirect Reported Indirect Reported Indirect

$\begin{array}{lllllll}\text { Illinois } & 2.276 & 1.588 & 0.675 & 0.483 & 23.0 & 14.8 \\ \text { Indiana } & 2.098 & 1.546 & 0.624 & 0.468 & 23.4 & 15.1 \\ \text { Kentucky } & 2.100 & 1.560 & 0.614 & 0.468 & 24.6 & 16.4 \\ \text { Ohio } & 2.194 & 1.567 & 0.642 & 0.466 & 23.4 & 14.9 \\ \text { Pennsylvania } & 2.185 & 1.565 & 0.647 & 0.470 & 23.5 & 15.2 \\ \text { Hest Virginia } & 1.731 & 1.418 & 0.524 & 0.434 & 19.4 & 14.2\end{array}$

(a) Limited indirect response $=$ direct effect, plus effect of coal industry wages and salaries. Coal industry procurements other than labor are not affected.

\section{A.3 PRODUCTIVITY TRENDS}

We examined historical average earnings per worker reported in the REIS in the six states between 1970 and 1986 as a possible source of data on changes in labor productivity outside of coal mining. Table A.3 shows the results. We found some historical change in real earnings per worker (that 1 is, earnings per worker adjusted for inflation), but no systematic trend. As

\begin{tabular}{|c|c|c|c|c|c|c|c|c|c|}
\hline & 1970 & 1975 & 1980 & 1981 & 1982 & 1983 & 1984 & 1985 & 1986 \\
\hline $\begin{array}{l}\text { Illinois } \\
\text { Indiana } \\
\text { Kentucky } \\
\text { Ohio } \\
\text { Pennsylvania } \\
\text { W. Virginia }\end{array}$ & $\begin{array}{l}1.025 \\
1.052 \\
1.004 \\
1.063 \\
1.036 \\
1.008\end{array}$ & $\begin{array}{l}0.943 \\
1.042 \\
1.041 \\
1.048 \\
1.050 \\
1.046\end{array}$ & $\begin{array}{l}0.978 \\
1.007 \\
1.019 \\
1.001 \\
0.989 \\
1.038\end{array}$ & $\begin{array}{l}0.957 \\
0.997 \\
1.008 \\
0.987 \\
0.969 \\
1.026\end{array}$ & $\begin{array}{l}0.955 \\
0.978 \\
1.007 \\
0.976 \\
0.961 \\
1.026\end{array}$ & $\begin{array}{l}0.964 \\
0.986 \\
1.011 \\
0.988 \\
0.970 \\
1.005\end{array}$ & $\begin{array}{l}0.971 \\
0.990 \\
1.010 \\
0.995 \\
0.976 \\
1.003\end{array}$ & $\begin{array}{l}0.980 \\
0.994 \\
0.998 \\
0.995 \\
0.981 \\
0.998\end{array}$ & $\begin{array}{l}1 \\
1 \\
1 \\
1 \\
1 \\
1\end{array}$ \\
\hline
\end{tabular}

(a) Calculated from REIS total wages and salaries, divided by total wage and salary employment, with wages adjusted for inflation relative to 1986 consumer prices. 
a consequence, we assumed that, outside the coal industry, real wages per worker would remain constant throughout the forecast period. This not quite the same as assuming constant labor productivity in a11 industries. Productivity and average wages in individual firms and industries could continue to rise (or fall), as long as enough lower (higher) paid jobs are added to the economy of the state to keep average real wages constant. In reality, it is probably to be expected that average real wages would increase somewhat over the next 10 to 15 years. If so, each individual worker would account for a larger share of income in each industry than is currently the case and the employment effects discussed in this report would be proportionately overest imated.

\section{A.4 EFFECTS OF STATE AND LOCAL GOVERNMENT SPENDING AND BUSINESS INVESTMENT}

The RIMS II modeling system results in what are called "Type II" multipliers. The Type II multiplier accounts for the interindustry purchases of businesses and the purchases of the household sector that occur in a given state when there is an increase in final demand for goods and services in the state's economy (say, an increase in export sales). However, the Type II multiplier does not account for changes in government spending and business investment that may occur as a result of growth or shrinkage of the state's economy, changes that may be caused by a decline in state government sales and income tax collections, for example, or changes in investment that may occur because of a deterioration in "business climate". Typically, state and

local government spending and business investment are considered "exogenous," or outside the economic model because the analyst does not want to (or can't) specify a simple rule by which these two sources of economic activity change as the level of overall economic activity changes. However, the effects may still be important and ignoring them may cause a substantial understatement of the total economic response to a change in final demand. Illustrative results on the potential size of the understatement have been worked out for an input-output based model of the economy of the State of Washington by Bourque, Conway, and Howard (1977), and later published by Conway (1979). Table A.4 shows that at the end of ten years, an increase in the value of exports of one dollar causes from 15 to 48 percent additional value added in 
TABLE A.4. A Comparison of Type II Value Added Multipliers With Value Added Multiplier Effects that Include Business Investment and State and Local Government Spending Effects, for a Permanent $\$ 1$ Increase in Washington State Exports in Selected Industries $(a)$

$\begin{array}{lcccc}\text { Industry } & \begin{array}{c}\text { Type II } \\ \text { Value Added } \\ \text { Multiplier }\end{array} & \begin{array}{c}\text { Multiplier With } \\ \text { Induced State and } \\ \text { Local Spending, } \\ \text { Business Investment }\end{array} & & \begin{array}{c}\text { Ratio to } \\ \text { Type II } \\ \text { Value Added } \\ \text { Multiplier }\end{array} \\ \text { Aerospace } & 0.86 & & 1.01 & 1.17 \\ \text { Logging } & 1.49 & 1.85 & 1.24 \\ \text { Pulp Mills } & 1.18 & 1.59 & 1.35 \\ \text { Petroleum } & 0.40 & 0.46 & 1.15 \\ \text { Aluminum } & 0.75 & 1.11 & 1.48 \\ \text { Trade } & 1.53 & 2.19 & 1.43\end{array}$

(a) Adapted from Bourque, Conway, and Howard, 1977, p. 118.

the Washington state economy over and above the Type II multiplier effect when the effects of induced government spending and business investment are added in.

Although coal mining was not among the industries studied by Bourque, Conway, and Howard, and a]though the results shown in Table A.4 apply to the State of Washington rather than one of the six states in the current study (for which we know of no comparable analysis), the results suggest that Type II multipliers may understate the total economic effects of changes in final demand by about $25 \%$ in a "typical" industry. More specific research is needed, however, for coal mining in the six state area to confirm this.

\section{A.5 A COMPARISON OF IMPACTS WITH DIFFERENT MODELS}

PNL researchers made contact with a number of economic researchers in the states being analyzed in this report, inquiring as to the availability of economic models that could be used to estimate the offsite economic impacts of changes in coal production associated with acid deposition control legislation. Table A.5 lists the models turned up in our search of these local sources. 
IABLE A.5. List of Economic Models of the States Affected by Changes in Coal Production

Mode]

Illinois

Indiana

Kentucky

Ohio

Pennsylvania

West Virginia

Type
Econometric
Econometric
Input/output

toutput

Input/output

Econometric

Input/output
Comments

Use model from Regional Economic Models Inc.

Same as Above.

Prepared by University of Kentucky. Non-survey. Constructed for 1982 from national table using demand/supply balance technique. (Mattas, Pagoulatos, and Debert in, 1984.)

Little data available e.g., Ro, 1982.

Use model from Wharton School Department of Econometrics

Prepared by University of West Virginia. Non-survey, interregional. Constructed from national table using trade data from Census of Transportation, commodity-byindustry accounting. (Greenstreet 1987a, 1987b.)

Table A.6 shows relatively large differences between the output impact estimates using RIMS II versus the alternative methodology in Kentucky and relatively small differences in West Virginia. However, the RIMS II models do differ considerably from the local models in the estimates they produce of payroll and employment impacts. This may be attributable both to differences in methodologies used to estimate the tables and to differences in data used. All the models were based in one way or another on the BEA input/output table for the nation, but not always on the same table or with the same degree of specificity. The 39 sector RIMS II system, for example, is based on the 537 sector 1977 BEA national input/output table. The 440 sector West Virginia model was based on the 1977 U.S. input/output table, updated to 1982, while 
IABLE A.6. Impacts of Changes in Coal Production in 1995 from the Mitchell Acid Rain Control Bill on State Economies Under Rims II Versus Local Alternative Models

\begin{tabular}{|c|c|c|c|c|}
\hline State & $\begin{array}{c}\text { Direct } \\
\text { Change in Coal } \\
\text { Industry in } \\
1995 \\
\end{array}$ & $\begin{array}{l}1995 \\
\text { Total } \\
\text { Effect } \\
\text { Under } \\
\text { RIMS II } \\
\end{array}$ & $\begin{array}{c}1995 \\
\text { Total } \\
\text { Effect } \\
\text { Under Loca] } \\
\text { Alternative (a) } \\
\end{array}$ & $\begin{array}{l}\text { Absolute } \\
\text { Percent } \\
\text { Difference } \\
\text { In Total } \\
\text { Effect } \\
\end{array}$ \\
\hline \multirow[t]{2}{*}{ Eastern Kentucky } & $\begin{array}{l}\text { Employment: } \\
+3,750 \text { Jobs }\end{array}$ & $+10,950$ Jobs & $+18,900$ Jobs & $+72.6 \%$ \\
\hline & $\begin{array}{l}\text { Value of Output: } \\
\$ 422 \mathrm{M}\end{array}$ & $\$ 886 \mathrm{M}$ & $\$ 1,396 \mathrm{M}$ & +57.6 \\
\hline \multirow[t]{2}{*}{ Western Kentucky } & $\begin{array}{l}\text { Employment: } \\
-1,300 \text { Jobs }\end{array}$ & $-5,650$ Jobs & $-6,200$ Jobs & +9.7 \\
\hline & $\begin{array}{l}\text { Value of Output: } \\
-\$ 253 \mathrm{M}\end{array}$ & $-\$ 531 M$ & $-\$ 837 M$ & +57.6 \\
\hline \multirow[t]{2}{*}{$\begin{array}{l}\text { Northern } \\
\text { West Virginia }\end{array}$} & $\begin{array}{l}\text { EmpToyment: } \\
-1,300 \text { Jobs }\end{array}$ & $-4,200$ Jobs & $-3,300$ Jobs & -21.4 \\
\hline & $\begin{array}{l}\text { Value of Output: } \\
-\$ 238 \mathrm{M}\end{array}$ & $-\$ 412 M$ & $-\$ 390 \mathrm{M}$ & -5.3 \\
\hline \multirow[t]{2}{*}{$\begin{array}{l}\text { Southern } \\
\text { West Virginia }\end{array}$} & $\begin{array}{l}\text { Employment: } \\
-2,600 \text { Jobs }\end{array}$ & $+6,650$ Jobs & $+4,550$ Jobs & -31.6 \\
\hline & $\begin{array}{l}\text { Value of Output: } \\
\quad+\$ 327 \mathrm{M}\end{array}$ & $+\$ 566 \mathrm{M}$ & $\$ 537 \mathrm{M}$ & -5.1 \\
\hline
\end{tabular}

(a) Kentucky: Mattas, Pagoulatos, and Debertin, 1984; West Virginia: Greenstreet 1987a, 1987b.

the 58-sector Kentucky model was based on the 1972 U.S. table, updated to 1982. Aggregation clearly plays a role in the differences between the local Kentucky table and the RIMS II table for Kentucky, but the differences are more subtle in the West Virginia model. The Hest Virginia model has inexplicably low direct income effects for changes in coal production. These effects are two orders of magnitude lower than in either the Kentucky model or the RIMS II models (e.g., 0.9 cents per dollar of final demand in the local model, 35.8 cents in RIMS 1 I for Hest Virginia), whereas one would 
expect them to be roughly equal. (a) As a result, the induced impacts in the West Virginia model may be too low. However, without a more complete understanding of the apparent discrepancy in the local West Virginia model, we are unable to reconcile the local model's result with RIMS II.

Table A.7 shows some implicit Type II multipliers calculated from the forecasts in the Year 1995. The low direct earnings estimate implies an exceptionally high implicit Type II multiplier for earnings in the West Virginia local model. The differences between RIMS II and the local Kentucky model seem to be largely the result of a somewhat different output multiplier. An attempt was made to compare the output multipliers for RIMS II and the local Kentucky model at the individual 2-digit SIC industry level; however, there was no single apparent difference between the models that would account for the higher multiplier in the local model. Rather, there

IABLE A.7. Type II Coa] Mining Implicit Multipliers, 1995(a)

\begin{tabular}{ccr} 
Kentucky & RIMS II & Local Mod \\
Output & 2.100 & \\
Income & 2.015 & 3.306 \\
Employment & 3.030 & 2.814 \\
& & 5.058 \\
West Virginia & & \\
Output & 1.731 & 1.641 \\
Income & 1.722 & 10.000 \\
Employment & 2.320 & 1.832 \\
\hline
\end{tabular}

(a) Total impact/direct change; e.g., total earnings in state divided by direct earnings in coal mining.

(a) The result is all the more difficult to understand because direct employment coefficients reported for the West Virginia local model are similar to those in other models. For example, the local model reports direct employment effects of 8.907 direct jobs per million dollars of final demand (and therefore, only $\$ 1,000$ per job) while the RIMS II model reports 8.4 direct jobs per million (or an income of $\$ 42,619$ per job, a much more reasonable figure). We contacted the author of the West Virginia model, who insisted that the reported multipliers were not misprints but a result of the estimation methodology. 
were a series of differences between the individual sector multipliers of different algebraic signs. In each case, to decide whether the RIMS II system or the local model is the more accurate or "correct" would take a research effort beyond the scope of this study. 


\section{DISTRIBUTION}

No. of

Copies

OFFSITE

10 DOE/Office of Scientific and Technical Information

B. McLean

U.S. Environmental Protection Agency

401 "M" Street, S.W.

Washington, DC 20460

5 T. Pitton

U.S. Environmental Protection Agency

401 "M" Street, S.W.

Washington, DC 20460

3 J. Schakenbach

U.S. Environmental Protection Agency

401 "M" Street, S.W.

Washington, DC 20460

3 P. Schwengels

U.S. Environmental Protection Agency

401 " $\mathrm{M}^{n}$ Street, S.W.

Washington, DC 20460

D. Tirpak

U.S. Environmental Protection Agency

401 "M" Street, S.W.

Washington, DC 20460
No. of

Copies

ONSITE

DOE Richland Operations office

J. J. Sutey

24 Pacific Northwest Laboratory

R. C. Darwin

S. J. Guthrie

F. 1. Johnson

R. J. Nesse (3)

M. J. Scott (10)

E. J. Stenehjem

Publishing Coordination (2)

Technical Report Files (5) 
